Hydrol. Earth Syst. Sci. Discuss., https://doi.org/10.5194/hess-2018-387

Manuscript under review for journal Hydrol. Earth Syst. Sci.

Discussion started: 20 August 2018

\title{
Wildfire impact on Boreal hydrology: empirical study of the Västmanland fire 2014 (Sweden)
}

\author{
Rafael Pimentel $^{1}$, Berit Arheimer ${ }^{1}$ \\ ${ }^{1}$ Hydrology Research Unit, Swedish Meteorological and Hydrological Institute, Folkborgsvägen 17, 601 76, Norrköping,
} 5 Sweden

Correspondence to: Rafael Pimentel (rafael.pimentel@.smhi.se)

\begin{abstract}
Land cover changes at watershed scale constitute key issues in general hydrology. Wildfires are one of the drivers of the changes in vegetation, which might affect hydrological fluxes and the water balance. The Västmanland fire in central Sweden burned 14000 hectares and removed the Boreal forest in this area during the summer 2014. In here, we have studied

10 the change in flow signatures during 3 years after the wildfire. In the empirical experiment we used a paired catchment methodology to compared 2 catchments highly affected by the wildfire with 2 unaffected catchments nearby, of similar character and climate to avoid the impact of natural variability in the analysis of wildfire impact. The average size of the catchments is $20 \mathrm{~km}^{2}$ and a total of 23 catchment characteristics of flow and physiography were defined, trying to isolate each of the hydrological processes affected by the wildfire. We used both in situ flow measurements and remote sensing

15 information (e.g. yearly volume at the outlet of the subbasins, fraction of vegetation or fraction of snow). The results show a change in the snow dynamics over the burnt areas with shorter duration of the snow season and a higher stream flow during autumn. This is probably related to an earlier snowmelt due to an increase indecent solar radiation over the snow cover without the canopy and the change in interception and transpiration from vegetation after the wildfire, respectively.
\end{abstract}

\section{Introduction}

20 The largest forest wildfire in Swedish modern history took place in Västmanland region, south-central Sweden, in the summer of 2014. The extremely high temperatures during the beginning of the summer, 3.5 degrees above the mean over this region, and the small precipitation, $25 \%$ offset for a normal July, favoured the development of the fire, which was ignited by a forest vehicle performing subsoiling. The wildfire was active from the $31^{\text {st }}$ of July till the $17^{\text {th }}$ of August affecting a total area of 14000 hectares (continuous black line in Figure 1). Most part of the affected area was covered by coniferous, needle-leaved evergreen forest belonging to the southern part of the boreal forest (Bodin and Nohrstedt, 2016; Lidskog and Sjödin, 2016).

Land cover constitutes one of the crucial components controlling hydrological processes and river flow at basin and regional scales (e.g. Blöschl et al., 2007; Hall et al., 2014) and alterations in its distribution have direct impacts in timing and magnitude on different component in energy and water budget (Bronstert et al., 2002; Cassiani et al., 2015; Tianming et al.,

30 2013; Scanlon et al., 2005). Forest wildfires are the most common non-direct anthropogenic changes that drastically may 
Hydrol. Earth Syst. Sci. Discuss., https://doi.org/10.5194/hess-2018-387

Manuscript under review for journal Hydrol. Earth Syst. Sci.

Discussion started: 20 August 2018

(c) Author(s) 2018. CC BY 4.0 License.

change the land cover across a large area. Forests work as a natural storage capable of absorbing and retaining rainfall during the wet season and releasing it slowly during the coming dry season (Calder, 2005; Qazi et al., 2017). Therefore, the most clear hydrological effects of a radical removal of vegetation will be related with the modification of the forest storage capacity and its interactions with the system. An increase in the total volume of effective precipitation (Madduma, 1974;

5 Crockford and Richardson, 2000; Jeffery et al., 2014) is the most direct consequence. Additional modification include the partition between soil and vegetation evaporation fluxes (Gerrits et al., 2010; Wang-Erlandsson et al., 2014) and soil moisture dynamics (Liancourt et al., 2012; van der Ent et al., 2014; Boer-Euser Tanja et al., 2016). Increasing soil evaporation can result in drier top soil with a subsoil that is wetter because the marked reduction in canopy transpiration (Silva et al., 2006). The switch in water runoff and consequently water discharges are the ultimate and more palpable

10 consequences. Higher runoff coefficients are expected after a big wildfire, which may also increase the erosion capacity (Cerda and Robichaud, 2009) and the consequent problem related with water quality due to an increasing number of suspended sediments (Löfgren et al., 2009; Smith et al., 2011). When the forest is located in snow dominated areas, such as the boreal forest, wildfires can also affect snow dynamics. Several studies have demonstrated that shift in forest structures impacts accumulation and melt properties (Faria et al., 2000; Micheletty et al., 2014). Snowpack is more exposed to solar

15 radiation with a lower snow albedo, due to the snow surface alteration from dust and rest of dead vegetation (Burles and Boon, 2011; Gleason et al., 2013; Painter. et al., 2007).

All these impacts are extremely conditioned by scale (Blöschl and Sivapalan, 1995). Most of the mentioned hydrological changes can be clearly observed at plot-scales (Beeson et al., 2001; Brown et al., 2005; Woods and Balfour, 2008; Ebel et al., 2012; Stoof et al., 2012; Harpold et al., 2014). However their direct extension at large scales, e.g. catchment-scale, can

20 imply an overestimation of the changes. Forest wildfire effects are smoothed, mixed, diluted or filtered at large scales (Cammeraat, 2002; Bracken and Croke, 2007). In this study we linked information from stream flow gauges with remote sensing products to quantify the areal impact of the catchments studied. Remote sensing products constitute an excellent tool to monitor land cover changes at medium-large scales, facilitating extra information to the traditional discharge measurements in gauge station that allows linking hydrologic effects with the real land cover changes.

25 Although wildfire hydrological effects are well documented in low and mid latitudes, where warm and dry conditions favour wildfire occurrence (Hulbert, 1969; Lavabre et al., 1993; Moody and Martin, 2001; Onda et al., 2008; Micheletty et al., 2014), there is lack of studies about its effects in cold regions. The wetter condition, periodical snow coverage, and the vegetation characteristics of boreal forests, make wildfire a phenomenon less recurrent in the North. However, the current global warming situation may impact hydrological regime with changes in precipitation, evaporation and snow (Arheimer 30 and Lindström, 2015). Scholze et al. (2006) show circumpolar boreal regions as highland venerable, with high risk of boreal forest losses and with an increasing wildfire frequency, especially in eastern Canada. This increase in wildfire frequency is not yet shown in Swedish boreal forest; nevertheless the destructive Västmanland forest wildfire, is a clear example of the consequences of a drastically/extreme change in climate can cause to the land system. 
Hydrol. Earth Syst. Sci. Discuss., https://doi.org/10.5194/hess-2018-387

Manuscript under review for journal Hydrol. Earth Syst. Sci.

Discussion started: 20 August 2018

(c) Author(s) 2018. CC BY 4.0 License.
Hydrology and

Earth System

Sciences

Discussions

(c) $\oplus$

In this context, the aims of this study are: (1) to assess the changes in land cover that the wildfire produced in system, and (2) to understand the hydrological effects that these land cover shifts introduced in the wildfire affected areas. For that, different indicators were defined to exclude natural variability, detect land-cover shifts and identify the eventual changes in flow signatures before and after the wildfire. A paired catchment methodology (Brown et al., 2005), commonly used to study

5 changes in the hydrological system after vegetation shifts, was used. Four small gauged catchments were examined; two affected by the wildfire with different intensities and two non-affected, respectively.

\section{Study site and available data}

This study was carried out in four small gauged catchments, in which two were affected by the wildfire to $94 \%$ and $80 \%$ of

15 the area, respectively (catchments A and B, in red and orange respectively in Figure 1); and two non-affected catchments situated very close to the burnt area, with the same type of climate and original land cover $(\mathrm{C}$ and $\mathrm{D}$, marked with blue in Figure 1). In the paired catchment methods applied, the non-affected areas work as reference sites to validate that the impact that we discovered from the wildfire was not caused by natural climate variability of the system. All 4 studied catchments represent similar size, altitudes, slope and vegetation (Table 1).

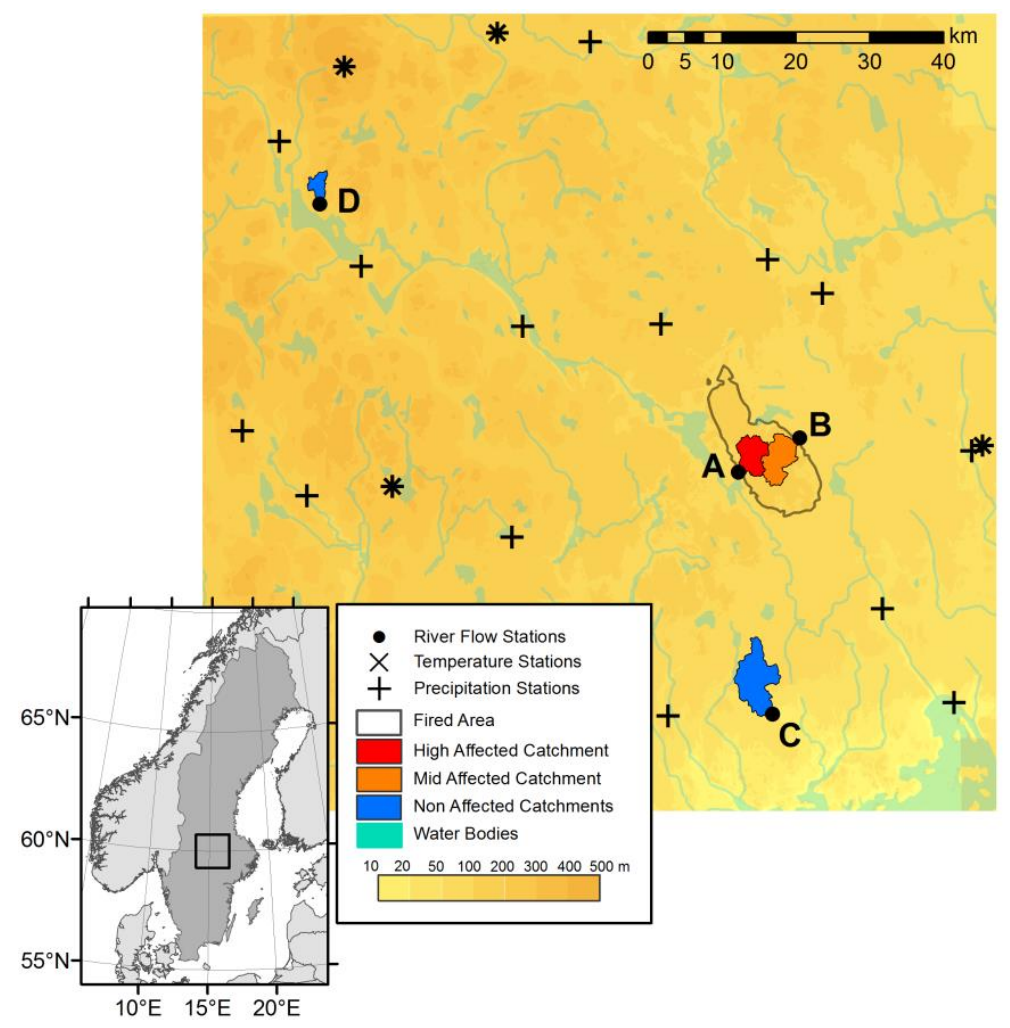

Figure 1 Location of the Västmanlan fire (black line) and the 4 small catchments analysed (in red, subbasin A, highly affected by the wildfire; in orange subbasin $B$, mid affected by the wildfire; in blue, subbasins $C$ and $D$, reference site unaffected by the wildfire) 
Hydrol. Earth Syst. Sci. Discuss., https://doi.org/10.5194/hess-2018-387

Manuscript under review for journal Hydrol. Earth Syst. Sci.

Discussion started: 20 August 2018

Table 1. Description of the catchments selected for the study: topographic and land cover descriptors and availability of discharge measurements in their outlets

\begin{tabular}{cccccccc}
\hline $\begin{array}{c}\text { Gauge } \\
\text { Station Name }\end{array}$ & $\begin{array}{c}\text { Gauge } \\
\text { Station ID }\end{array}$ & $\begin{array}{c}\text { Area affected by } \\
\text { the wildfire }(\%)\end{array}$ & $\begin{array}{c}\text { Catchment } \\
\text { area }\left(\mathbf{k m}^{2}\right)\end{array}$ & $\begin{array}{c}\text { Mean elevation } \\
(\mathbf{m} \text { a.s.l) }\end{array}$ & $\begin{array}{c}\text { Mean Slope* } \\
(\%)\end{array}$ & $\begin{array}{c}\text { Forest area } \\
(\%)\end{array}$ & $\begin{array}{c}\text { Monitored timeserie of } \\
\text { daily water discharge }\end{array}$ \\
\hline Vallsjöbäcken & A & 94 & 17.7 & 105 & 6.0 & 0.94 & $1979-01-01-2001-01-08$ \\
Gärsjöbäcken & B & 80 & 22.5 & 109 & 3.2 & $2014-11-12-2017-09-30$ \\
Svenbybäcken & C & 0 & 36.5 & 56 & 2.3 & 0.80 & $2014-09-10-2016-10-05$ \\
Finntorget & $\mathrm{D}$ & 0 & 7.0 & 259 & 8.6 & 0.86 & $1980-08-31-2017-09-30$ \\
\hline
\end{tabular}

(*Calculated using the digital elevation model (DEM) GSD Terrain elevation databank (50x50m) from Lantmäteriet (cadastral and land registration Swedish authority); and 5

defined as the average value of slope in each DEM cell within the catchment)

Three main sources of information were used in the study. First, Earth Observations (EO) products to evaluate the changes in land cover. The MODIS/Terra (MOD13Q1) and the MODIS/Aqua (MYD13Q1) Vegetation Indexes (VI) version 006 were employed to evaluate the changes in vegetation before and after the wildfire (Didan, 2015a, 2015b). These two products have spatial and temporal resolutions of $250 \mathrm{~m}$ and 16 days, respectively (Table 2). However, the combinations of both

10 products, which have a time overlap, permits increase the temporal resolution from 16 to 8 days. Among the two VI available, Normalized Difference Vegetation Index (NDVI; Tucker, 1979) is used in this study. To assess the variability on the snow distribution, the MODIS/Terra Snow Cover (MOD10A2) version 006 is used (Hall and Riggs, 2016). This product provided eight-day maximum snow extent observation at $500 \mathrm{~m}$ resolution generated from Normalized Difference Snow Index (NDSI; Dozier, 1989).

Table 2 Summary of Earth Observation (EO) used in the study. Spatiotemporal resolution, available dates and the number of scenes/dates analysed (the wildfire was located between two of the MODIS tiles with sometimes did not have the same availability, for this reason the table makes a difference between them)

\begin{tabular}{cccccc}
\hline Land Cover & Product/version & $\begin{array}{c}\text { Spatial Res. } \\
(\mathbf{m})\end{array}$ & $\begin{array}{c}\text { Temp. Res. } \\
\text { (days) }\end{array}$ & Available period & $\begin{array}{c}\text { Number dates analysed } \\
\text { (tile name) }\end{array}$ \\
\hline Vegetation & MOD13Q1/006 & 250 & 16 & $2002-01-01-2017-09-14$ & $364(\mathrm{~h} 18 \mathrm{v} 03)-358(\mathrm{~h} 18 \mathrm{v} 02)$ \\
& MYD13Q1/006 & 250 & 16 & $2002-07-04-2017-06-18$ & $334(\mathrm{~h} 18 \mathrm{v} 03)-350(\mathrm{~h} 18 \mathrm{v} 02)$ \\
Snow & MOD10A2/006 & 500 & 8 & $2000-02-18-2017-09-30$ & $805(\mathrm{~h} 18 \mathrm{v} 03)-807(\mathrm{~h} 18 \mathrm{v} 02)$ \\
\hline
\end{tabular}

Second, discharge measurements at gauges station located in the outlet of the selected catchments were used. Gauge stations A, B and C (Figure 1 and Table 1) were measuring flow before the wildfire and are part of the national monitoring network of stream flow run by the Swedish Meteorological and Hydrological Institute (SMHI) across the country. These stations measure the water level every 15 minutes, a discharge value is then computed using a site-specific rating curve for each station and a daily average is calculated for river flow. Gauge station D, was installed after the wildfire by the Swedish 
Hydrol. Earth Syst. Sci. Discuss., https://doi.org/10.5194/hess-2018-387

Manuscript under review for journal Hydrol. Earth Syst. Sci.

Discussion started: 20 August 2018

(c) Author(s) 2018. CC BY 4.0 License.
Hydrology and

Earth System

Sciences

Discussions

(c) (i)

University of Agricultural Sciences (SLU) using a Doppler, which measures changes in pressure of the water vs a reference on land, which is then transformed into stream flow from a site-specific rating curve. Gaps in flow discharge time series, (periods 2002-2014 and 2000-2014 for gauging station A and B, respectively) were filled with flow discharges calculated by S-HYPE, national multi-basin model system for Sweden (Lindström et al., 2010; Strömqvist et al., 2012). The model

5 performance for the study sites was evaluated for each of the defined flow signatures (see Appendix material Table A1); concluding that only significant changes between model and observations appear for the signature the annual number of reversal (Rev).

Third, meteorological data were achieved from the national database PTHBV at SMHI, which is a $5 \mathrm{~km}$ gridded product of daily precipitation and temperature. It is based on observed data from some 700 meteorological stations across the country of

10 Sweden $\left(450000 \mathrm{~km}^{2}\right)$ which has been processed using optimal interpolation (i.e. kriging) with variables such as wind direction, altitude, slope, radiation, land cover to produce the grid (Johansson, 2002). The meteorological stations used by the gridded product and nearby the selected catchments, 18 station for precipitation and 4 for temperature, are shown in Figure 1.

\section{Methodology}

15 Hydrological changes in the study sites were analysed using the paired catchment methodology regarding: a) natural climate variability; b) land cover changes in vegetation and snow; and c) characteristic flow signatures during the period before the wildfire (2000-10-01 to 2014-09-30) and after the wildfire (2014-10-01 to 2017-09-30), respectively. The flow signatures were chosen to characterize different shapes of the hydrograph and flow regimes with importance to hydro-ecology based on the suggested metrics by Olden and Poff (2003) and Kuentz et al. (2017). In total, the 23 descriptors ( 2 for climate, 5 for land cover and 16 for flow signatures) were defined to detect and evaluate changes in each study site (Table 3). Climate and land cover descriptors were aggregated to the area of each one of the selected catchments and flow signatures were computed from measured or modelled time-series (see above Section 2). Climate descriptors were only used to validate that the unaffected reference sites were representing undisturbed conditions for the catchments affected by the wildfire, to make sure that the analysis were not biased by natural variability. 
Hydrol. Earth Syst. Sci. Discuss., https://doi.org/10.5194/hess-2018-387

Manuscript under review for journal Hydrol. Earth Syst. Sci.

Discussion started: 20 August 2018

Table 3 Definition of the descriptors used to evaluate the hydrological changes over the wildfire area, regarding: a) climate, b) land cover and c) flow signature

\begin{tabular}{|c|c|c|c|c|}
\hline \multicolumn{2}{|l|}{ Descriptor } & Variable & Units & Description \\
\hline \multicolumn{5}{|l|}{ Climate } \\
\hline & & Prec & $\mathrm{mm}$ & total annual/monthly precipitation \\
\hline & & Tem & degrees & annual/monthly mean temperature \\
\hline \multicolumn{5}{|l|}{ Land Cover } \\
\hline Vegetation & & FVeg & - & $\begin{array}{l}\text { annual/monthly Fractional Vegetation Cover } \\
\text { (derive from NDVI following (Gutman and } \\
\text { Ignatov, 1998)) }\end{array}$ \\
\hline \multirow[t]{4}{*}{ Snow } & Magnitude & FSC & - & annual/monthly Fractional Snow Cover \\
\hline & Duration & SnowIni & $\begin{array}{l}\text { day of the } \\
\text { hydrological } \\
\text { year (DOHY) }\end{array}$ & $\begin{array}{l}\text { Beginning of the snow season, defined as the first } \\
\text { day with more that } 10 \% \text { FSC in the watershed }\end{array}$ \\
\hline & & SnowEnd & $\begin{array}{l}\text { day of the } \\
\text { hydrological } \\
\text { year (DOHY) }\end{array}$ & $\begin{array}{l}\text { Ending of the snow season, defined as the first } \\
\text { day with more that } 10 \% \text { FSC in the watershed }\end{array}$ \\
\hline & & SnowDays & days & Duration of the snow season \\
\hline \multicolumn{5}{|l|}{ Flow Signatures } \\
\hline \multirow[t]{7}{*}{$\begin{array}{l}\text { Magnitude of } \\
\text { flow events }\end{array}$} & $\begin{array}{l}\text { Average flow } \\
\text { conditions }\end{array}$ & Skew & - & $\begin{array}{l}\text { annual } / \text { monthly skewness }=\text { mean } / \text { median of daily } \\
\text { flows }\end{array}$ \\
\hline & & Qsp & $\mathrm{mm}$ & annual/monthly mean specific flow \\
\hline & & CVQ & & $\begin{array}{l}\text { annual } / \text { monthly coef variation }=\mathrm{SD} / \text { mean daily } \\
\text { flow }\end{array}$ \\
\hline & $\begin{array}{l}\text { Low flow } \\
\text { conditions }\end{array}$ & BFI & - & $\begin{array}{l}\text { Base Flow Index: 7-day minimum flow divided by } \\
\text { mean annual/monthly flow }\end{array}$ \\
\hline & & Q5 & $\mathrm{mm}$ & $\begin{array}{l}\text { annual/monthly } 5^{\text {th }} \text { percentile of daily specific } \\
\text { flow }\end{array}$ \\
\hline & & HFD & & $\begin{array}{l}\text { annual/monthly High Flow Discharge: } 10^{\text {th }} \\
\text { percentile of daily flow divided by median daily } \\
\text { flow }\end{array}$ \\
\hline & & Q95 & $\mathrm{mm}$ & $5^{\text {th }}$ percentile of daily specific flow \\
\hline \multirow[t]{2}{*}{$\begin{array}{l}\text { Frequency } \\
\text { events of flow }\end{array}$} & $\begin{array}{l}\text { Low flow } \\
\text { conditions }\end{array}$ & LowFr & year $^{-1}$ & $\begin{array}{l}\text { total number of low flow spells (threshold equal to } \\
5 \% \text { of mean daily flow) }\end{array}$ \\
\hline & $\begin{array}{l}\text { High flow } \\
\text { conditions }\end{array}$ & HighFr & year $^{-1}$ & $\begin{array}{l}\text { total number of high flow spells (threshold equal } \\
\text { to } 50 \% \text { of mean daily flow) }\end{array}$ \\
\hline \multirow[t]{2}{*}{$\begin{array}{l}\text { Duration of the } \\
\text { flow events }\end{array}$} & $\begin{array}{l}\text { Low flow } \\
\text { conditions }\end{array}$ & LowDurVar & - & $\begin{array}{l}\text { coef. of var. in annual mean duration of low flow } \\
\text { (threshold } 25^{\text {th }} \text { percentile) }\end{array}$ \\
\hline & $\begin{array}{l}\text { High flow } \\
\text { conditions }\end{array}$ & Mean30dMax & - & $\begin{array}{l}\text { mean annual } 30 \text {-day maximum divided by median } \\
\text { flow }\end{array}$ \\
\hline $\begin{array}{l}\text { Timing of flow } \\
\text { events }\end{array}$ & & Const & - & annual constancy of daily flow (Colwell, 1974) \\
\hline \multirow[t]{2}{*}{$\begin{array}{l}\text { Rate of change } \\
\text { in flow events }\end{array}$} & & Rev & - & $\begin{array}{l}\text { annual number of reversals (change in the sign in } \\
\text { the day-to-day change time series) } \\
\text { annual/monthly Richard - Baker flashiness: sum }\end{array}$ \\
\hline & & RBFlash & - & $\begin{array}{l}\text { of absolute values of day-to-day changes in mean } \\
\text { daily flow divided by the sum of all daily flows }\end{array}$ \\
\hline \multirow[t]{2}{*}{$\begin{array}{l}\text { Catchment } \\
\text { response }\end{array}$} & & RunoffCo & - & $\begin{array}{l}\text { annual/monthly Runoff coefficient: ratio between } \\
\text { mean annual/monthly flow divided by mean } \\
\text { annual/monthly precipitation }\end{array}$ \\
\hline & & ActET & $\mathrm{mm} \mathrm{yr}^{-1} / \mathrm{month}^{-1}$ & $\begin{array}{l}\text { annual/monthly Actual Evapotranspiration: mean } \\
\text { annual/monthly precipitation minus mean } \\
\text { annual/monthly flow }\end{array}$ \\
\hline
\end{tabular}


Hydrol. Earth Syst. Sci. Discuss., https://doi.org/10.5194/hess-2018-387

Manuscript under review for journal Hydrol. Earth Syst. Sci.

Discussion started: 20 August 2018

(c) Author(s) 2018. CC BY 4.0 License.

(c) (i)
Hydrology and

Earth System

Sciences

Discussions

Two different analyses were performed to evaluate the changes. First, temporal evolution of the main descriptors (Prec,

Temp, FVeg, FSC and Qsp) was assessed for the pre- and post-wildfire periods. These time-series were analysed by visual inspection and metrics for changes in trends. Second, annual and/or monthly values, depending on the descriptor definition, of each descriptor during pre- and post-wildfire period were compared. Mann-Whitney U test or Wilcoxon rank-sum test

5 (Mann and Whitney, 1947) was performed to evaluate if the changes were statistically significant. This test is a nonparametric test used to test whether two samples are likely to derive from the same population.

\section{Results}

Table 4 shows that only 11 of the 23 defined descriptors were exposed to statistical significant changes after the wildfire on the annual scale, according to the Mann-Whitney $U$ test. Nevertheless, none of these significant changes are constant

10 throughout the year; instead they are being significant only under specific months, and can thus be linked to processes controlling the hydrological fluxes during these events.

Table 4 Statistical significance of the Mann-Whitney $U$ test for the changes between pre- and post- wildfire in all descriptors defined for each catchment (A to D, Figure 1) on the annual and seasonal scales: 1) High significance $(99 \%)$ increase $(\ddagger)$ and decrease $(=) ; 2)$ Normal significance $(95 \%)$ increase $(+)$ and decrease $(-)$; 3 ) No significance, $(\cdot)$; 4) Non defined descriptor (blank), due to descriptor definition or values out of season in the case of snow and vegetation.

\begin{tabular}{|c|c|c|c|c|c|c|c|c|c|c|c|c|c|}
\hline & \multirow{2}{*}{$\begin{array}{l}\text { Annual } \\
\text { ABCD }\end{array}$} & \multicolumn{12}{|c|}{ Seasonal } \\
\hline & & $\begin{array}{c}\text { Oct } \\
\text { ABCD }\end{array}$ & $\begin{array}{c}\text { Nov } \\
\text { ABCD }\end{array}$ & $\begin{array}{c}\text { Dec } \\
\text { ABCD }\end{array}$ & $\begin{array}{c}\text { Jan } \\
\text { ABCD }\end{array}$ & $\begin{array}{c}\text { Feb } \\
\text { ABCD }\end{array}$ & $\begin{array}{c}\text { Mar } \\
\text { ABCD }\end{array}$ & $\begin{array}{c}\text { Apr } \\
\text { ABCD }\end{array}$ & $\begin{array}{c}\text { May } \\
\text { ABCD }\end{array}$ & $\begin{array}{c}\text { Jun } \\
\text { ABCD }\end{array}$ & $\begin{array}{c}\text { Jul } \\
\text { ABCD }\end{array}$ & $\begin{array}{c}\text { Aug } \\
\text { ABCD }\end{array}$ & $\begin{array}{c}\text { Sep } \\
\text { ABCD }\end{array}$ \\
\hline Prec & $\cdots$ & $\cdots$ & $\cdots$ & $\cdots$ & $\cdots$ & $\cdots$ & $\cdots$ & $\cdots$ & $\cdots$ & $\cdots$ & $\cdots$ & $\cdots$ & ++++ \\
\hline Temp & ++++ & ++++ & ++++ & $\ddagger \ddagger \ddagger \ddagger$ & $\cdots$ & $\cdots$ & $\cdots$ & $\cdots$ & $\cdots$ & $\cdots$ & $\ldots$ & $\ldots$ & $\ddagger \ddagger \ddagger \ddagger$ \\
\hline Fveg & $--\cdots$ & & & & & & $\ldots$ & $--\cdot$ & $--\cdot$ & $--\cdot$ & $--\cdots$ & $--\cdots$ & $--\cdot$ \\
\hline FSC & $--\cdots$ & $\cdots$ & $--\cdots$ & $\ldots$ & $\ldots$ & $\ldots$ & $\ldots$ & $\cdots$ & & & & & \\
\hline SnowIni & $+\cdots$ & & & & & & & & & & & & \\
\hline SnowEnd & $--\cdots$ & & & & & & & & & & & & \\
\hline SnowDays & $--\cdots$ & & & & & & & & & & & & \\
\hline Skew & $==\cdots$ & $\ldots$ & $\ldots$ & $\ldots$ & $\ldots$ & $\ldots$ & $\ldots$ & $\ldots$ & $\ldots$ & $\ldots$ & $\ldots$ & $\ddagger \ddagger \cdots$ & $\ldots$ \\
\hline Qsp & $\cdots$ & $\cdots$ & $\cdots$ & $\cdots$ & $\cdots$ & $\cdots$ & $\cdots$ & $\cdots$ & $\cdots$ & $\cdots$ & $\cdots$ & $\cdots$ & $+\cdots$ \\
\hline CVQ & $\ldots$ & $\ldots$ & $\ldots$ & $\ldots$ & $\ldots$ & $\ldots$ & $\ldots$ & $\ldots$ & $\ldots$ & $\ldots$ & $++\cdots$ & $\ddagger \ddagger \cdots$ & $\ldots$ \\
\hline BFI & $\cdots$ & & & & & & & & & & & & \\
\hline Q5 & $\ldots$ & $\cdots$ & $\cdots$ & $\ldots$ & $\ldots$ & $\cdots$ & $\cdot+++$ & $\cdots$ & $\cdots$ & $\cdots$ & $\cdots$ & $\cdots$ & $+\cdots$ \\
\hline HFD & $\cdots$ & $\cdots$ & $\cdots$ & $\cdots$ & $\cdots$ & $+\cdots$ & $\cdots$ & $\cdot+\cdots$ & $\cdots$ & $\cdots$ & $--\cdots$ & $\cdots$ & $\cdots$ \\
\hline Q95 & $\cdots--$ & $\cdots$ & $\cdots$ & $\cdots$ & $--\cdot-$ & $\cdots$ & $\cdots$ & $\cdots$ & $\ldots$ & $\ldots$ & $\cdots$ & $\cdots$ & $++\cdots$ \\
\hline LowFr & $\cdots$ & & & & & & & & & & & & \\
\hline HighFr & $\ldots$ & & & & & & & & & & & & \\
\hline LowDurVar & $--\cdots$ & & & & & & & & & & & & \\
\hline Mean30Max & $--\cdots$ & & & & & & & & & & & & \\
\hline Const & $\cdots$ & & & & & & & & & & & & \\
\hline Rev & $\cdots \ddagger$ & & & & & & & & & & & & \\
\hline RBFlash & $\cdots$ & $\cdots$ & $\cdot+\cdots$ & $\cdots$ & $\cdots$ & $++\cdots$ & $\cdots$ & $\cdots$ & $++\cdots$ & $\cdots-$ & $\cdots$ & $\ddagger \ddagger \cdots$ & $\cdot+\cdots$ \\
\hline RunoffCo & $\cdots$ & $\cdots$ & $\cdots$ & $\cdots$ & $\cdots$ & $\cdots$ & $\cdots$ & $\cdots$ & $\cdots$ & $\cdots$ & $\cdots$ & $\cdots$ & $\ddagger+\cdots$ \\
\hline ActET & $\ldots$ & $\ldots$ & $\ldots$ & $\ldots$ & $\ldots$ & $\ldots$ & $\ldots$ & $\ldots$ & $\ldots$ & $\ldots$ & $\ldots$ & $\ldots$ & --- \\
\hline
\end{tabular}


Hydrol. Earth Syst. Sci. Discuss., https://doi.org/10.5194/hess-2018-387

Manuscript under review for journal Hydrol. Earth Syst. Sci.

Discussion started: 20 August 2018

(c) Author(s) 2018. CC BY 4.0 License.
Hydrology and

Earth System

Sciences

Discussions

(c) (i)
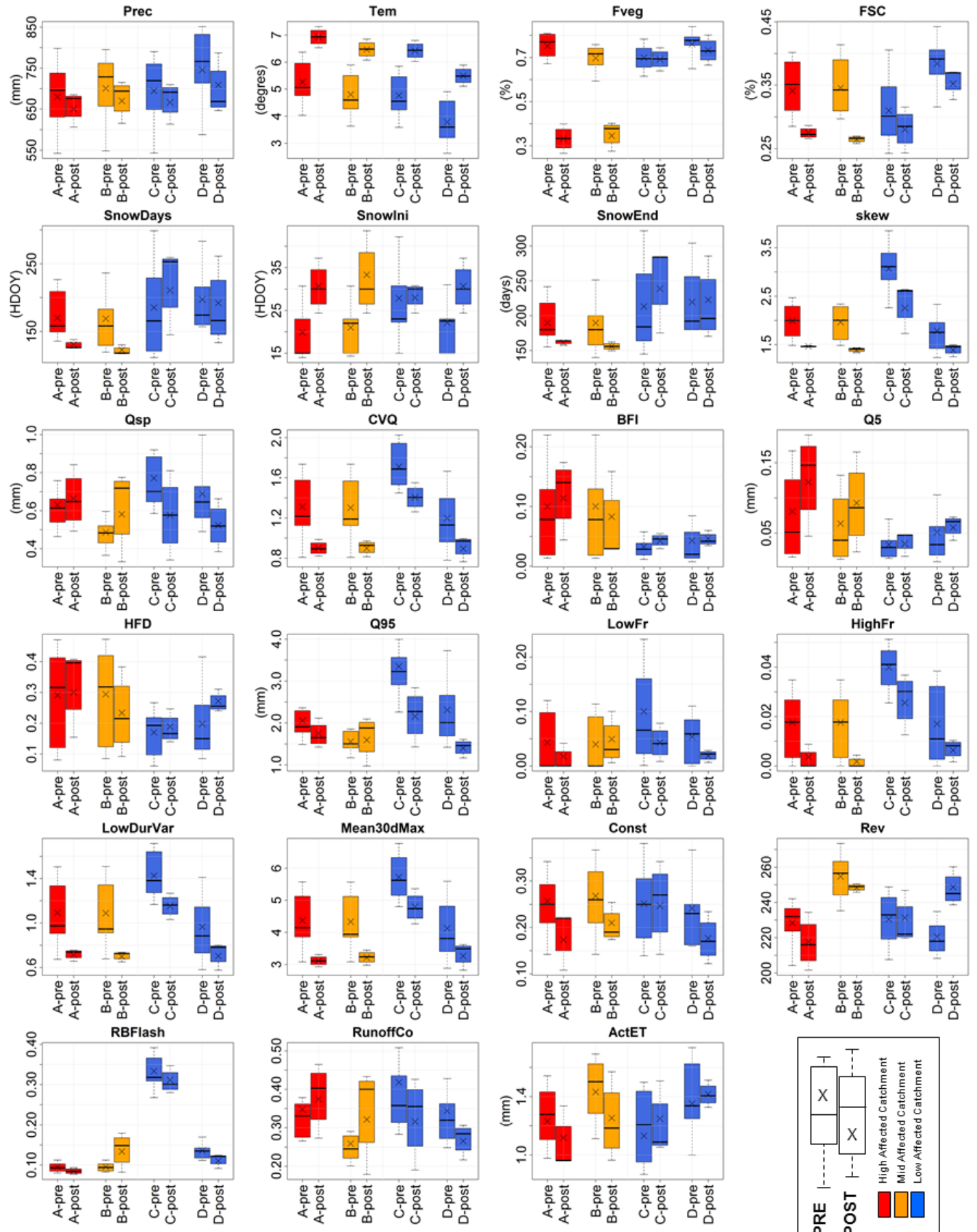

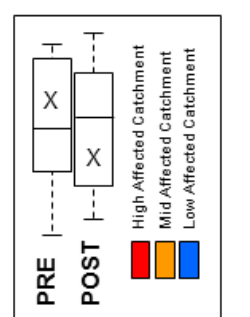

Figure 2. Distribution of annual values of the 23 descriptor for the pre- and post-wildfire period in each of the four selected sites. The box shows $50 \%$ of the data, solid line is the median value and $x$ is the mean value of the dataset (in total 17 samples, 14 and 3 respectively in each dataset). Red box represent high affected site; orange box the medium affected site and blue boxes represents the non-affected catchments. 
Hydrol. Earth Syst. Sci. Discuss., https://doi.org/10.5194/hess-2018-387

Manuscript under review for journal Hydrol. Earth Syst. Sci.

Discussion started: 20 August 2018

(c) Author(s) 2018. CC BY 4.0 License.

(c) (i)
Hydrology and

Earth System

Sciences

Discussions

The climate variables show some variability between the two periods studied, with temperature being higher during the years after the wildfire, mainly due to warmer autumn and winter seasons (Fig. 2). However, the same temperature effect is detected in both affected areas and reference sites. Precipitation, on the other hand, was relatively stable, with only some lower values for the month of September. Again, the changes are similar in all catchments studied, which indicate that any

5 further differences found between the catchments cannot be related to natural variability. The results illustrate the importance of considering climate variability in comparative studies, as this factor control much of the water dynamics and may pollute the findings when exploring other causes to hydrological change.

When studying time-series from the EO products, land cover showed significant changes for all studied variables between

10 the catchments affected by the wildfire and reference sites on the annual scale. The results clearly show that for vegetation the growing season is from April to September, while the snow season ranges from October to April in this region.

Significant differences between wildfire affected and reference sites were found only for 5 of the 16 flow-signatures studied. Looking into specific months, however, gave significant differences during specific months in 10 signatures, as described

15 more in detail below (also see the Appendix section, Figure A2).

\subsection{Shifts in Climate and Land cover}

Both temperature and precipitation show similar pattern for the 4 chosen sites after the wildfire (Figure 3) and thus, climate cannot be considered as the dominant driving factor to explain the differences between catchments affected or not affected by the wildfire. During the post-wildfire years a clear increase, about $5{ }^{\circ} \mathrm{C}$, in mean daily mean temperature occurred

20 between autumn and early winter (Oct-Jan), while the rest of the months showed the same values as in the pre-wildfire period. This reflects the natural weather fluctuations between years and could be observed in all 4 catchments. The changes in annual cumulative daily precipitation are negligible, only some small significant change can be observed during September. 
Hydrol. Earth Syst. Sci. Discuss., https://doi.org/10.5194/hess-2018-387

Manuscript under review for journal Hydrol. Earth Syst. Sci.

Discussion started: 20 August 2018

(I)

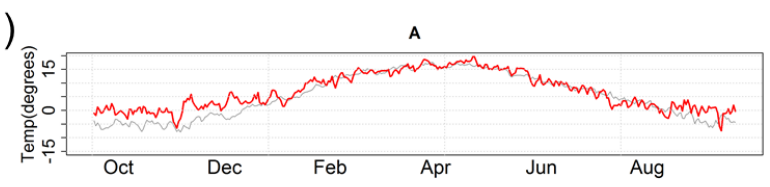

(II)

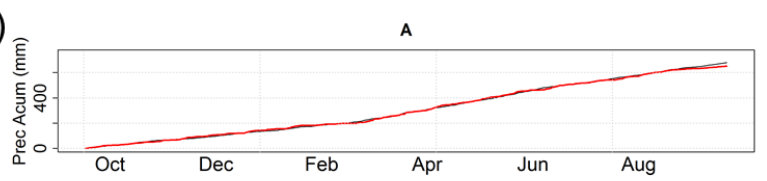

B

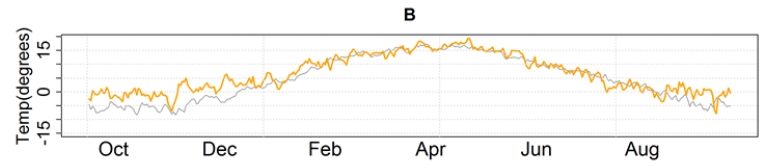

c
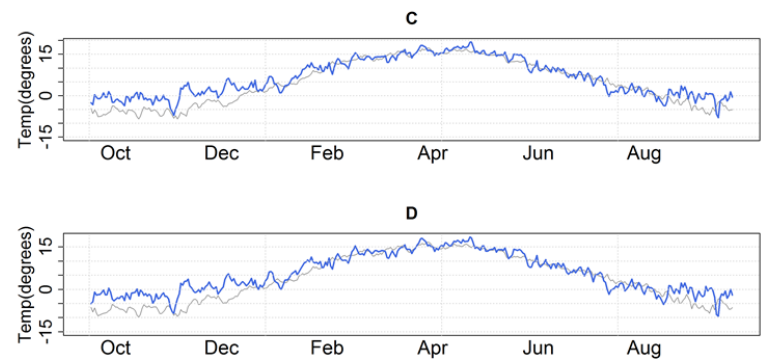

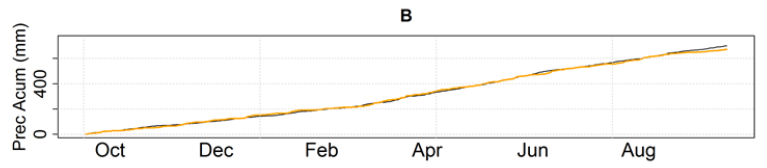

c

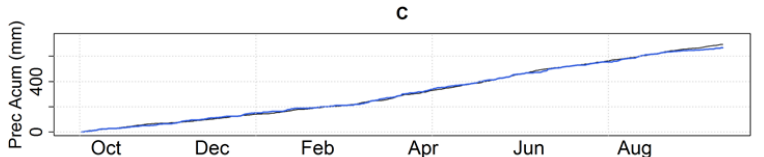

D

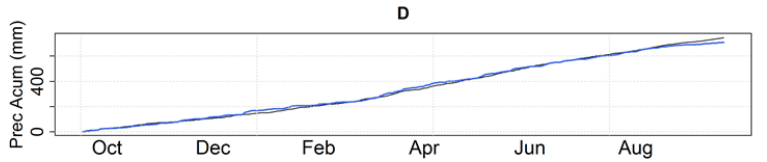

Figure 3 Seasonal evolution of climate variables: (I) mean daily temperature (left panel) and (II) annual cumulative daily precipitation (right panel) for pre-wildfire (grey lines) and post-wildfire (coloured lines) periods in each of the four catchments.

5 The drastic change in vegetation during the wildfire and the following vegetation recover was clearly identified by EO products (Figure $4 \mathrm{I}$ ). The affected area is not fully recovered after 3 years; however, some vegetation is now growing here again. The satellite product shows that about half of the affected area has recovered some type vegetation with annual mean values of fraction of vegetation cover for the third year after the wildfire of 0.42 ( 0.75 in the pre-wildfire period) for site $\mathrm{A}$ and 0.44 (0.69 in the pre-wildfire period) for site B. Similar recovery rate are observed in both sites for the first year, about $42 \%$ per year, however this rate change during the second year with higher recovery in site A, $15 \%$ per year, than in site B, $6 \%$ per year. The satellite information used in this study cannot distinguish which kind of vegetation has replaced the original boreal coniferous forest; however, some field campaign show that mosses, small shrubs and isolated pines trees have started to grow in the affected area (Figure A3). As expected no changes in vegetation were found in the non-affected reference sites. 
Hydrol. Earth Syst. Sci. Discuss., https://doi.org/10.5194/hess-2018-387

Manuscript under review for journal Hydrol. Earth Syst. Sci.

Discussion started: 20 August 2018

(c) Author(s) 2018. CC BY 4.0 License.

(I)

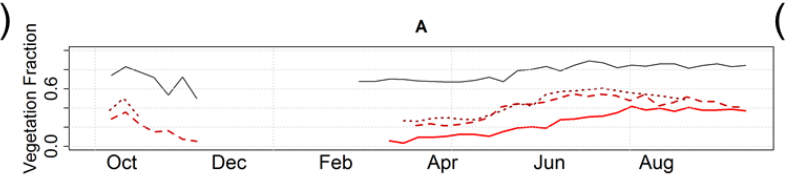

B

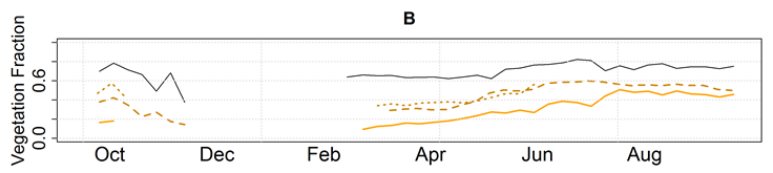

(II)

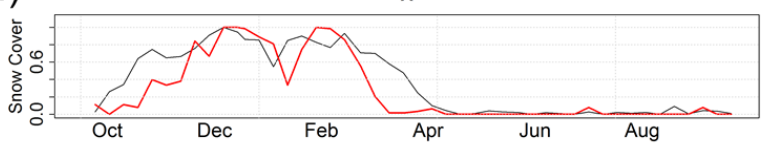

B

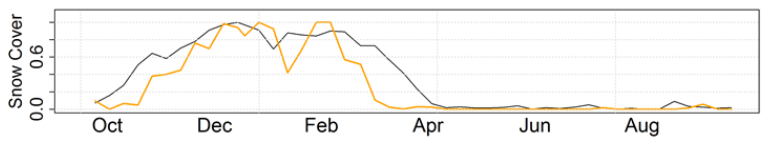

C

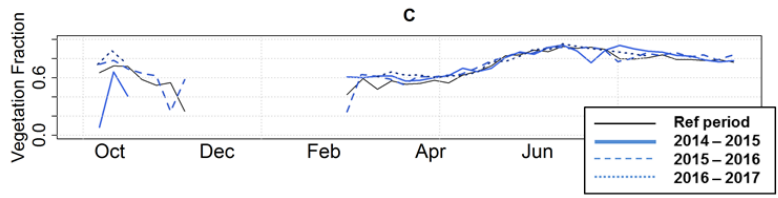

D

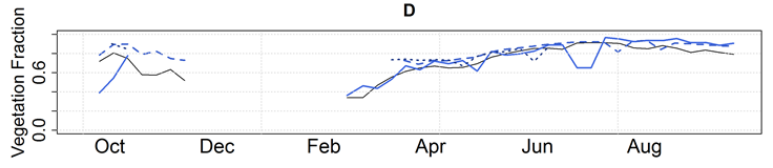

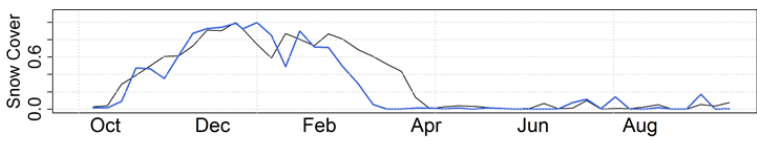

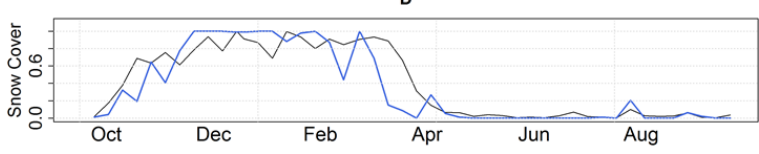

Figure 4. Seasonal evolution of land cover descriptors: (I) daily fractional vegetation area (left panel) and (II) daily fractional snow cover (right panel) for pre-wildfire (grey lines) and post-wildfire (coloured lines) periods in each of the four catchments.

5 Similarly, the catchments affected by the wildfire also show a clear change in snow cover evolution (Figure 4), with a significant reduction of the snow annual mean snow fractional cover. Although the duration of the snow season during the post-wildfire period is shorter in all studied sites, the change is only statistically significant in the areas affected by the wildfire (A and B). This is a consequence of the clear shift in onset and end of the snow accumulation phases, which change 15 and 9 days (in median for A and B respectively) for the beginning of the snow season, and 15 and 21 days for the snow-

10 season ending. This effect is not seen in the reference site and is thus not caused by higher temperatures but rather by the loss of forest canopy (Figure 2, boxplot 1). The higher exposure to shortwave radiation due to the loss of forest vegetation hinders the snow accumulation at the onset of the snow period and favours the melting at the end of the snow season.

\subsection{Impact on Flow signatures}

Time-series analysis of stream flow does not show any significant change in water volumes, however, a peakier behaviour

15 can be found in mean condition of the flow after the wildfire in affected areas (Figure 5 I). Regarding seasonality, a clear shift in the peak flow during March is shown after the wildfire in the affected sites, which is not seen in the reference sites (Figure 5 II). This change in flow dynamics is probably due to the earlier snowmelt onset observed after the wildfire in affected sites. In addition a more peaky flow was found during summer after the loss of vegetation. The lower interception and evapotranspiration due to lack of vegetation canopy, as well as lower capacity to retain water due to loss of soil during the wildfire event, are probably two main factors controlling these higher peak in summer period. Similar results have been 
Hydrol. Earth Syst. Sci. Discuss., https://doi.org/10.5194/hess-2018-387

Manuscript under review for journal Hydrol. Earth Syst. Sci.

Discussion started: 20 August 2018

reported in several studies world-wide (e.g. Evans et al., (1999) in Australia, Inbar et al., (1998) in Israel and Moody and Martin, (2001) in western USA).
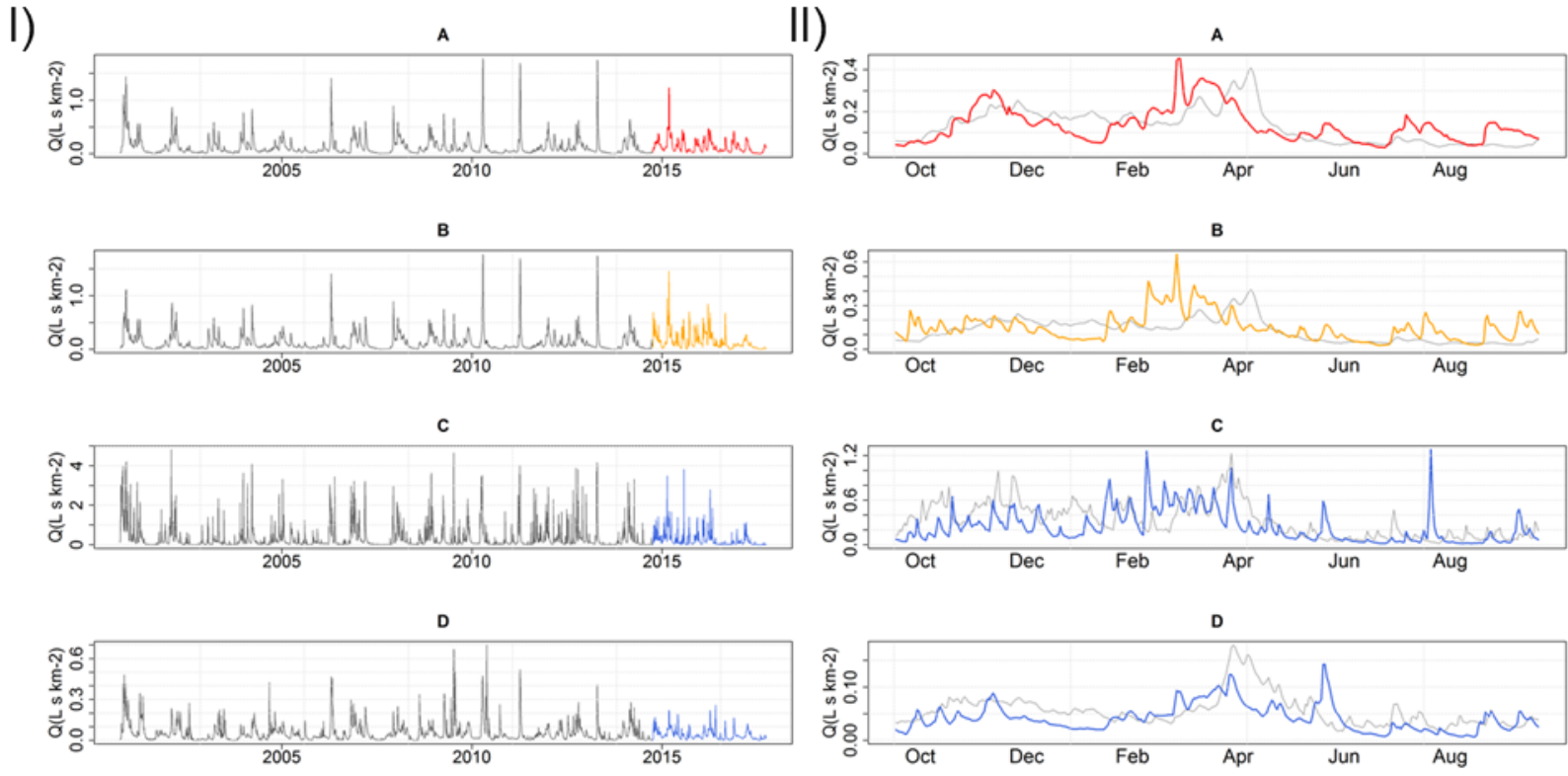

5 Figure 5 Temporal evolution (left panel) and (II) Seasonal evolution (right panel) of daily flow for pre-wildfire (grey lines) and post-wildfire (coloured lines) periods in each of the four catchments.

The boxplots of Figure 2 confirms these time-series analysis. Regarding magnitude of the flow events, a statistically significant decrease was found for skewness and coefficient of variation after the wildfire in burnt areas, in addition to a less influence from climate on high flows. This means that the variation in flow is less extreme after the wildfire, with closer values between mean and median flows and smaller standard deviation. Again, the changes in water storages due to a quicker snow melting, with shorter snow season, are the main causes of the less pronounced flow peaks. The same causes generate statistically significant differences in flow duration, with less durable period of both low and high flow conditions (Figure 2). Hence, both lower peak flows and lower duration of the peak flows due to the wildfire were affected.

15 For the studied flow signatures that illustrate frequency, timing, rate of change in the event and catchment response, no significant changes were observed between affected areas and the reference sites at annual scale; however, changes in flow signatures on the monthly scale were detected. Especially during September when we had a significant change in precipitation and temperatures between the two periods studied (see section 4.1), which resulted in significant higher mean specific flow, base flow, high flow, and runoff, while actual evapotranspiration was much lower. Probably the loss of

20 vegetation and soil affected the storage capacity of the precipitation at these events. Higher flashiness during the summer 
Hydrol. Earth Syst. Sci. Discuss., https://doi.org/10.5194/hess-2018-387

Manuscript under review for journal Hydrol. Earth Syst. Sci.

Discussion started: 20 August 2018

period (August) was found after the wildfire, which may be due to more water available due to lack of interception and evapotranspiration from the canopy and lower storage capacity from canopy and soil loss during the wildfire event.

\section{Discussion}

Three main changes in the hydrological regime could be observed due to the loss of vegetation and tree canopy after the

5 wildfire: change in magnitude and timing of snow-melt peak, change in consecutive flow conditions and flashiness from rainfall-events. These changes could be attributed to changes in hydrological drivers, such as shorter period of snow storage, lower interception, lower infiltration capacity and evapotranspiration, resulting in changed magnitude of the fluxes generated before and after the wildfire (Figure 6).

Regarding changes in snow dynamics, the main finding is a reduction of the duration of snow season with a mean reduction

10 of 18 days after the wildfire for the years and sites analysed. This effect is also found in similar studies over the Sierra Nevada Mountains (California) (Micheletty et al., 2014) and boreal forest in Oregon (Gleason et al., 2013), with a mean reduction of 7.5 days and a 23 days earlier snowmelt in the wildfire sites, respectively. This faster snowmelt, which could reach double rating (Gary, 1974) between affected versus non-affected areas, can be explain by the bigger amount of available energy in the open/wildfire affected areas. Berris and Harr (1987) quantified $40 \%$ more energy available for

15 melting in clear cut area than in a forest one. Sensible and latent heat fluxes are bigger; more shortwave radiation is reaching the snowpack without the tree cover. The forest canopy also shelters the snow surface from wind, greatly decreasing the efficiency of turbulent energy fluxes (Link and Marks, 1999). Therefore, a high exposition to wind is a direct consequence of forest loss, with the direct increasing of turbulent fluxes and a quicker melting. Lower albedo due to charred soil and truck also contribute changing the energy balance (Gary, 1974; Gleason Kelly et al., 2013). In addition, snow interception may be

20 drastically reduced. According to Pomeroy and Schmidt, (1993) 60\% of the total snowfall is intercepted by the boreal forest, with a direct sublimation loss than can be $30-40 \%$ of the total intercepted snow. Snow interception is the main driver for the snow to reach the soil (Smith et al., 2011) and also the source for evaporation, but from dead tree branches it is almost negligible. 

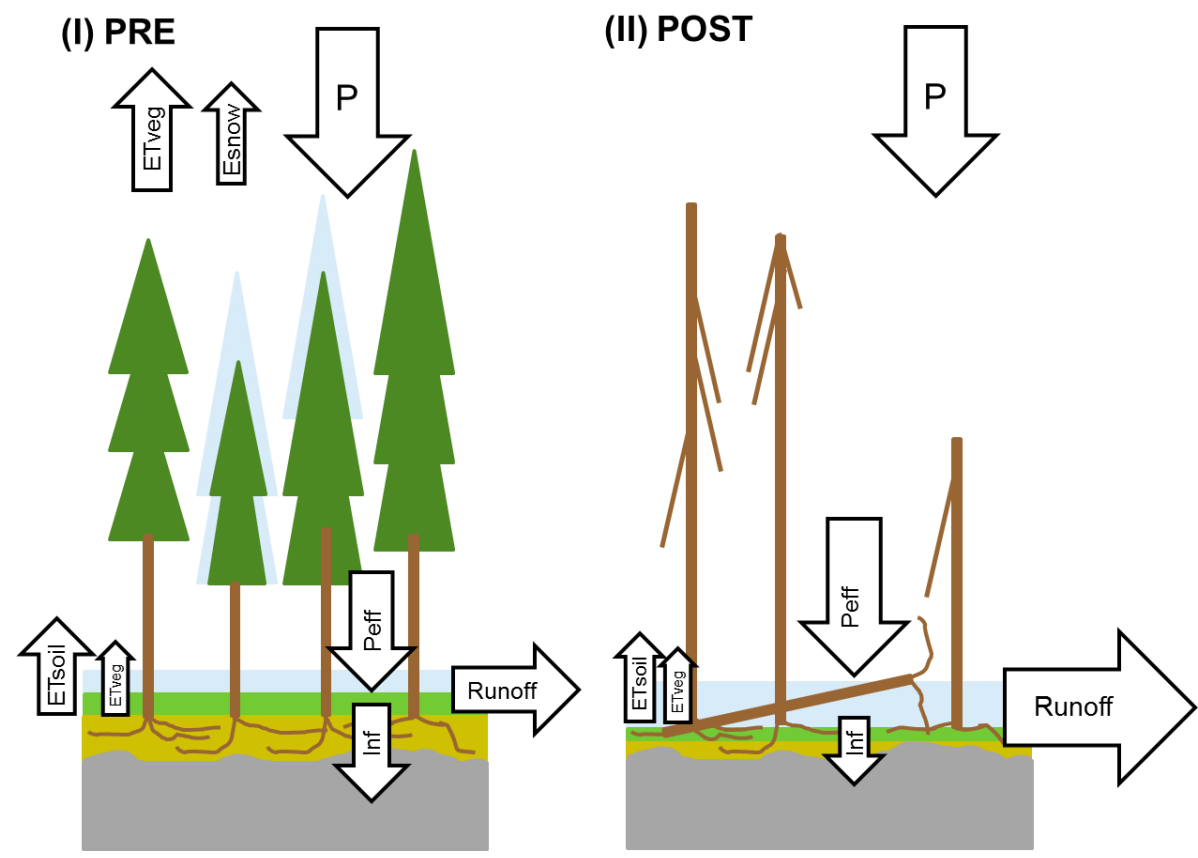

Figure 6. Conceptual Scheme of water bucket and fluxes in the system before and after the wildfire. The size of the arrows means the importance of the flux in the system.

Regarding changes in consecutive flow conditions and flashiness from rainfall-events, the wildfire altered the interception, infiltration and evapotranspiration dynamics with clear variations during the summer period, more peaky flow, less evapotranspiration and more runoff, only statistically significant during September. The affected area was composed mainly by shallow rocky outcrops and well-drained mineral soils (Bohlin et al., 2017) which after the wildfire were completely remove or highly decreased in depth (see Figure A3 in the Appendix). Therefore, the capacity of the soil to store water was completely diminished, altering the runoff and evaporation dynamics. The flashiness is also affected by shifts in interception and evapotranspiration. The forest interception capacity, which in boreal forest can range between 20-30\% (Grelle et al., 1999), has completely changed after the wildfire. Regarding evapotranspiration, Grelle et al. (1997) decomposed the evapotranspiration for a nearby experimental site into $65 \%$ transpiration and $20 \%$ evaporation of the intercepted precipitation

15 in the canopy, and $15 \%$ coming from soil evaporation. Therefore, without the canopy, the two main components in the evaporation do not play a role. More water is able to evaporate but the new characteristic of the system are not able to do it, and consequently, the catchment response quickly to precipitation events. However, this quick response is less significant during winter period when the role of the snowpack storing water delay the runoff effects. 
Hydrol. Earth Syst. Sci. Discuss., https://doi.org/10.5194/hess-2018-387

Manuscript under review for journal Hydrol. Earth Syst. Sci.

Discussion started: 20 August 2018

\section{Conclusions}

This empirical study of the wildfire impact on Boreal hydrology shows that:

- The loss of tree canopy has changed the infiltration, interception, evapotranspiration and snow patterns; not only modifying the capacity of soil, vegetation and snow to retain water but also altering the water fluxes between them.

- Hydrological changes on the annual scale were found in relation to snow season duration and its consequent spring flow peak. In addition, changes in the flow skewness and variation coefficient were detected in the affected areas after the wildfire. Only changes in specific summer months were found for shifts in evaporation and runoff.

- The paired catchment methodology used was found to be very useful. Comparing nearby reference sites with the ones affected by the wildfire made it possible to separate natural variability from the wildfire impact in the hydrological interpretation of the data. Separating the time series into flow signatures, made it possible to identify changes which were not seen in simple time-series analysis. Finally, the use of EOs helped both to identify the extension of burnt areas and to assess the vegetation recovery after the wildfire. After three years, half of the fractional vegetation cover has been recovery. However, the EO product used cannot distinguish which are new vegetation types.

\section{Acknowledgements}

This work has been funded by The Swedish Research Council FORMAS (Project: Collecting records from the Västmanland forest-fire: to explore spatial and temporal patterns of changes in water flow) in Grant Agreement No. 2014-01850. The study was performed at the SMHI Hydrological Research unit, working as a team with contributions from many co-workers. We especially thank Johan Strömqvist, David Gustafsson and Göran Lindström for contributing to this study with discussions and advices.

\section{References}

Arheimer, B. and Lindström, G.: Climate impact on floods: changes in high flows in Sweden in the past and the future (1911-2100), Hydrol. Earth Syst. Sci., 19(2), 771-784, doi:10.5194/hess-19-771-2015, 2015.

25 Beeson C., Martens N. and Breshears D.: Simulating overland flow following wildfire: mapping vulnerability to landscape disturbance, Hydrological Processes, 15(15), 2917-2930, doi:10.1002/hyp.382, 2001.

Berris, N. and Harr, D.: Comparative snow accumulation and melt during rainfall in forested and clear-cut plots in the Western Cascades of Oregon, Water Resources Research, 23(1), 135-142, doi:10.1029/WR023i001p00135, 1987. 
Hydrol. Earth Syst. Sci. Discuss., https://doi.org/10.5194/hess-2018-387

Manuscript under review for journal Hydrol. Earth Syst. Sci.

Discussion started: 20 August 2018

(c) Author(s) 2018. CC BY 4.0 License.

Blöschl G. and Sivapalan M.: Scale issues in hydrological modelling: A review, Hydrological Processes, 9(3-4), 251-290, doi:10.1002/hyp.3360090305, 1995.

Blöschl, G., Ardoin-Bardin, S., Bonell, M., Dorninger, M., Goodrich, D., Gutknecht, D., Matamoros, D., Merz, B., Shand, P. and Szolgay, J.: At what scales do climate variability and land cover change impact on flooding and low flows?, Hydrological Processes, 21(9), 1241-1247, doi:10.1002/hyp.6669, 2007.

Bodin, Ö. and Nohrstedt, D.: Formation and performance of collaborative disaster management networks: Evidence from a Swedish wildfire response, Global Environmental Change, 41, 183-194, doi:10.1016/j.gloenvcha.2016.10.004, 2016.

Boer-Euser T., McMillan H., Hrachowitz M., Winsemius H. and Savenije H.: Influence of soil and climate on root zone storage capacity, Water Resources Research, 52(3), 2009-2024, doi:10.1002/2015WR018115, 2016.

Bohlin, I., Olsson, H., Bohlin, J. and Granström, A.: Quantifying post-fire fallen trees using multi-temporal lidar, International Journal of Applied Earth Observation and Geoinformation, 63, 186-195, doi:10.1016/j.jag.2017.08.004, 2017.

Bracken L. and Croke J.: The concept of hydrological connectivity and its contribution to understanding runoffdominated geomorphic systems, Hydrological Processes, 21(13), 1749-1763, doi:10.1002/hyp.6313, 2007.

Bronstert A., Niehoff D. and Bürger G.: Effects of climate and land-use change on storm runoff generation: present knowledge and modelling capabilities, Hydrological Processes, 16(2), 509-529, doi:10.1002/hyp.326, 2002.

Brown, A. E., Zhang, L., McMahon, T. A., Western, A. W. and Vertessy, R. A.: A review of paired catchment 20 studies for determining changes in water yield resulting from alterations in vegetation, Journal of Hydrology, 310(1), 28-61, doi:10.1016/j.jhydrol.2004.12.010, 2005.

Burles K. and Boon S.: Snowmelt energy balance in a burned forest plot, Crowsnest Pass, Alberta, Canada, Hydrological Processes, 25(19), 3012-3029, doi:10.1002/hyp.8067, 2011.

Calder, I. R.: Blue Revolution: Integrated Land and Water Resources Management, 2nd edition., Routledge, 25 London; Sterling, VA., 2005.

Cammeraat L. H.: A review of two strongly contrasting geomorphological systems within the context of scale, Earth Surface Processes and Landforms, 27(11), 1201-1222, doi:10.1002/esp.421, 2002.

Cassiani, G., Boaga, J., Vanella, D., Perri, M. T. and Consoli, S.: Monitoring and modelling of soil-plant interactions: the joint use of ERT, sap flow and eddy covariance data to characterize the volume of an orange tree root zone, Hydrol. Earth Syst. Sci., 19(5), 2213-2225, doi:10.5194/hess-19-2213-2015, 2015.

Cerda, A.: Fire Effects on Soils and Restoration Strategies, CRC Press., 2009.

Colwell R. K.: Predictability, Constancy, and Contingency of Periodic Phenomena, Ecology, 55(5), 1148-1153, doi:10.2307/1940366, 1974. 
Hydrol. Earth Syst. Sci. Discuss., https://doi.org/10.5194/hess-2018-387

Manuscript under review for journal Hydrol. Earth Syst. Sci.

Discussion started: 20 August 2018

(c) Author(s) 2018. CC BY 4.0 License.

Hydrology and

Earth System

Sciences

Discussions

Crockford R. H. and Richardson D. P.: Partitioning of rainfall into throughfall, stemflow and interception: effect of forest type, ground cover and climate, Hydrological Processes, 14(16-17), 2903-2920, doi:10.1002/10991085(200011/12)14:16/17<2903::AID-HYP126>3.0.CO;2-6, 2000.

DeFries R. and Eshleman K. N.: Land-use change and hydrologic processes: a major focus for the future,

Hydrological Processes, 18(11), 2183-2186, doi:10.1002/hyp.5584, 2004.

Didan, K.: MOD13Q1 MODIS/Terra Vegetation Indices 16-Day L3 Global 250m SIN Grid V006, NASA EOSDIS LP DAAC [online] Available from: doi: 10.5067/MODIS/MYD13Q1.006, 2015a.

Didan, K.: MYD13Q1 MODIS/Aqua Vegetation Indices 16-Day L3 Global 250m SIN Grid V006, NASA EOSDIS LP DAAC, doi:doi: 10.5067/MODIS/MYD13Q1.006, $2015 \mathrm{~b}$.

10 Dozier, J.: Spectral signature of alpine snow cover from the landsat thematic mapper, Remote Sensing of Environment, 28, 9-22, doi:10.1016/0034-4257(89)90101-6, 1989.

Ebel, B. A., Hinckley, E. S. and Martin, D. A.: Soil-water dynamics and unsaturated storage during snowmelt following wildfire, Hydrol. Earth Syst. Sci., 16(5), 1401-1417, doi:10.5194/hess-16-1401-2012, 2012.

van der Ent, R. J., Wang-Erlandsson, L., Keys, P. W. and Savenije, H. H. G.: Contrasting roles of interception

15 and transpiration in the hydrological cycle - Part 2: Moisture recycling, Earth Syst. Dynam., 5(2), 471-489, doi:10.5194/esd-5-471-2014, 2014.

Evans, K. G., Saynor, M. J. and Willgoose, G. R.: Changes in hydrology, sediment loss and microtopography of a vegetated mine waste rock dump impacted by fire, Land Degradation \& Development, 10(6), 507-522, doi:10.1002/(SICI)1099-145X(199911/12)10:6<507::AID-LDR341>3.0.CO;2-\#, 1999.

20 Faria D. A., Pomeroy J. W. and Essery R. L. H.: Effect of covariance between ablation and snow water equivalent on depletion of snow-covered area in a forest, Hydrological Processes, 14(15), 2683-2695, doi:10.1002/1099-1085(20001030)14:15<2683::AID-HYP86>3.0.CO;2-N, 2000.

Gary, H.: Snow accumulation and snowmelt as influenced by a small clearing in a lodgepole pine forest, Water Resources Research, 10(2), 348-353, doi:10.1029/WR010i002p00348, 1974.

25 Gerrits A. M. J., Pfister L. and Savenije H. H. G.: Spatial and temporal variability of canopy and forest floor interception in a beech forest, Hydrological Processes, 24(21), 3011-3025, doi:10.1002/hyp.7712, 2010.

Gleason, K. E., Nolin , A. W. and Roth, T. R.: Charred forests increase snowmelt: Effects of burned woody debris and incoming solar radiation on snow ablation, Geophysical Research Letters, 40(17), 4654-4661, doi:10.1002/grl.50896, 2013.

30 Grelle, A., Lundberg, A., Lindroth, A., Morén, A.-S. and Cienciala, E.: Evaporation components of a boreal forest: variations during the growing season, Journal of Hydrology, 197(1), 70-87, doi:10.1016/S00221694(96)03267-2, 1997. 
Hydrol. Earth Syst. Sci. Discuss., https://doi.org/10.5194/hess-2018-387

Manuscript under review for journal Hydrol. Earth Syst. Sci.

Discussion started: 20 August 2018

(c) Author(s) 2018. CC BY 4.0 License.

Hydrology and

Earth System

Sciences

Discussions

(c) (i)

Grelle, A., Lindroth, A. and Mölder, M.: Seasonal variation of boreal forest surface conductance and evaporation, Agricultural and Forest Meteorology, 98-99, 563-578, doi:10.1016/S0168-1923(99)00124-0, 1999.

Gutman, G. and Ignatov, A.: The derivation of the green vegetation fraction from NOAA/AVHRR data for use in numerical weather prediction models, International Journal of Remote Sensing, 19(8), 1533-1543, doi:10.1080/014311698215333, 1998.

Hall, D.K. and Riggs, G. A.: MODIS/Terra Snow Cover 8-Day L3 Global 500m Grid, Version 6, Boulder, Colorado USA. NASA National Snow and Ice Data Center Distributed Active Archive Center., doi:doi.org/10.5067/MODIS/MOD10A2.006, 2016.

Hall, J., Arheimer, B., Borga, M., Brázdil, R., Claps, P., Kiss, A., Kjeldsen, T. R., Kriaučiūnienė, J., Kundzewicz, 10 Z. W., Lang, M., Llasat, M. C., Macdonald, N., McIntyre, N., Mediero, L., Merz, B., Merz, R., Molnar, P., Montanari, A., Neuhold, C., Parajka, J., Perdigão, R. A. P., Plavcová, L., Rogger, M., Salinas, J. L., Sauquet, E., Schär, C., Szolgay, J., Viglione, A. and Blöschl, G.: Understanding flood regime changes in Europe: a state-ofthe-art assessment, Hydrol. Earth Syst. Sci., 18(7), 2735-2772, doi:10.5194/hess-18-2735-2014, 2014.

Harpold, A. A., Biederman, J. A., Condon, K., Merino, M., Korgaonkar, Y., Nan, T., Sloat, L., Ross, M. and

15 Brooks, P. D.: Changes in snow accumulation and ablation following the Las Conchas Forest Fire, New Mexico, USA, Ecohydrology, 7(2), 440-452, doi:10.1002/eco.1363, 2014.

Huang, T., Pang, Z. and Edmunds, W. M.: Soil profile evolution following land-use change: implications for groundwater quantity and quality, Hydrological Processes, 27(8), 1238-1252, doi:10.1002/hyp.9302, 2013.

Hulbert, L.C.: Fire and Litter Effects in Undisturbed Bluestem Prairie in Kansas, Ecology, 50(5), 874-877, doi:10.2307/1933702, 1969.

Inbar, M., Tamir, M. and Wittenberg, L.: Runoff and erosion processes after a forest fire in Mount Carmel, a Mediterranean area, Geomorphology, 24(1), 17-33, doi:10.1016/S0169-555X(97)00098-6, 1998.

Jeffery M. L., Yanites B. J., Poulsen C. J. and Ehlers T. A.: Vegetation-precipitation controls on Central Andean topography, Journal of Geophysical Research: Earth Surface, 119(6), 1354-1375, doi:10.1002/2013JF002919, 2014.

Lavabre, J., Torres, D. S. and Cernesson, F.: Changes in the hydrological response of a small Mediterranean basin a year after a wildfire, Journal of Hydrology, 142(1), 273-299, doi:10.1016/0022-1694(93)90014-Z, 1993.

Liancourt, P., Sharkhuu, A., Ariuntsetseg, L., Boldgiv, B., Helliker, B. R., Plante, A. F., Petraitis, P. S. and Casper, B. B.: Temporal and spatial variation in how vegetation alters the soil moisture response to climate manipulation, Plant Soil, 351(1-2), 249-261, doi:10.1007/s11104-011-0956-y, 2012.

Lidskog, R. and Sjödin, D.: Extreme events and climate change: the post-disaster dynamics of forest fires and forest storms in Sweden, Scandinavian Journal of Forest Research, 31(2), 148-155, doi:10.1080/02827581.2015.1113308, 2016. 
Hydrol. Earth Syst. Sci. Discuss., https://doi.org/10.5194/hess-2018-387

Manuscript under review for journal Hydrol. Earth Syst. Sci.

Discussion started: 20 August 2018

(c) Author(s) 2018. CC BY 4.0 License.

Hydrology and

Earth System

Sciences

Discussions

(c) (i)

Lindström, G., Pers, C., Rosberg, J., Strömqvist, J. and Arheimer, B.: Development and testing of the HYPE (Hydrological Predictions for the Environment) water quality model for different spatial scales, Hydrology Research, 41(3-4), 295-319, doi:10.2166/nh.2010.007, 2010.

Link, T. and Marks, D.: Distributed simulation of snowcover mass- and energy-balance in the boreal forest,

5 Hydrological Processes, 13(14-15), 2439-2452, doi:10.1002/(SICI)1099-1085(199910)13:14/15<2439::AIDHYP866>3.0.CO;2-1, 1999.

Löfgren, S., Ring, E., von Brömssen, C., Sørensen, R. and Högbom, L.: Short-term Effects of Clear-cutting on the Water Chemistry of Two Boreal Streams in Northern Sweden: A Paired Catchment Study, AMBIO: A Journal of the Human Environment, 38(7), 347-356, doi:10.1579/0044-7447-38.7.347, 2009.

10 Madduma Bandara, C. M.: Drainage density and effective precipitation, Journal of Hydrology, 21(2), 187-190, doi:10.1016/0022-1694(74)90036-5, 1974.

Mann, H. B. and Whitney, D. R.: On a test of whether one of two random variables is stochasitcally larger than the other, Annals of Mathematical Statistics, 18(1), 60-70, 1947.

Micheletty, P. D., Kinoshita, A. M. and Hogue, T. S.: Application of MODIS snow cover products: wildfire

15 impacts on snow and melt in the Sierra Nevada, Hydrol. Earth Syst. Sci., 18(11), 4601-4615, doi:10.5194/hess18-4601-2014, 2014.

Moody, J. A. and Martin, D. A.: Initial hydrologic and geomorphic response following a wildfire in the Colorado Front Range, Earth Surface Processes and Landforms, 26(10), 1049-1070, doi:10.1002/esp.253, 2001.

Moody, J. A. and Martin, D. A.: Post-fire, rainfall intensity-peak discharge relations for three mountainous watersheds in the western USA, Hydrological Processes, 15(15), 2981-2993, doi:10.1002/hyp.386, 2001.

Olden, J. D. and Poff, N. L.: Redundancy and the choice of hydrologic indices for characterizing streamflow regimes, River Research and Applications, 19(2), 101-121, doi:10.1002/rra.700, 2003.

Onda, Y., Dietrich, W. E. and Booker, F.: Evolution of overland flow after a severe forest fire, Point Reyes, California, CATENA, 72(1), 13-20, doi:10.1016/j.catena.2007.02.003, 2008.

25 Painter, T. H., Barrett, A. P., Landry, C. C., Neff. J. C., Cassidy, M. P., Lawrence, C. R., McBride, K. E. and Farmer, G. L.: Impact of disturbed desert soils on duration of mountain snow cover, Geophysical Research Letters, 34(12), doi:10.1029/2007GL030284, 2007.

Pomeroy, J. and Schmidt, R.: The Use of Fractal Geometry in Modelling Intercepted Snow Accumulation and Sublimation, Quebec City, 1993.

30 Qazi, N. Q., Bruijnzeel, L. A., Rai, S. P. and Ghimire, C. P.: Impact of forest degradation on streamflow regime and runoff response to rainfall in the Garhwal Himalaya, Northwest India, Hydrological Sciences Journal, 62(7), 1114-1130, doi:10.1080/02626667.2017.1308637, 2017. 
Hydrol. Earth Syst. Sci. Discuss., https://doi.org/10.5194/hess-2018-387

Manuscript under review for journal Hydrol. Earth Syst. Sci.

Discussion started: 20 August 2018

Hydrology and

Earth System

(c) Author(s) 2018. CC BY 4.0 License.

Sciences

Discussions

(c) (i)

Sajikumar, N. and Remya, R. S.: Impact of land cover and land use change on runoff characteristics, Journal of Environmental Management, 161, 460-468, doi:10.1016/j.jenvman.2014.12.041, 2015.

Scanlon, B. R., Reedy, R. C., Stonestrom, D. A., Prudic, D. E. and Dennehy, K. F.: Impact of land use and land cover change on groundwater recharge and quality in the southwestern US, Global Change Biology, 11(10), 5 1577-1593, doi:10.1111/j.1365-2486.2005.01026.x, 2005.

Scholze, M., Knorr, W., Arnell, N. W. and Prentice, I. C.: A climate-change risk analysis for world ecosystems, PNAS, 103(35), 13116-13120, doi:10.1073/pnas.0601816103, 2006.

Silva, J. S., Rego, F. C. and Mazzoleni, S.: Soil water dynamics after fire in a Portuguese shrubland, Int. J. Wildland Fire, 15(1), 99-111, doi:10.1071/WF04057, 2006.

10 Smith, H. G., Sheridan, G. J., Lane, P. N. J., Nyman, P. and Haydon, S.: Wildfire effects on water quality in forest catchments: A review with implications for water supply, Journal of Hydrology, 396(1), 170-192, doi:10.1016/j.jhydrol.2010.10.043, 2011.

Stoof, C. R., Vervoort, R. W., Iwema, J., van den Elsen, E., Ferreira, A. J. D. and Ritsema, C. J.: Hydrological response of a small catchment burned by experimental fire, Hydrol. Earth Syst. Sci., 16(2), 267-285,

15 doi:10.5194/hess-16-267-2012, 2012.

Strömqvist, J., Arheimer, B., Dahné, J., Donnelly, C. and Lindström, G.: Water and nutrient predictions in ungauged basins: set-up and evaluation of a model at the national scale, Hydrological Sciences Journal, 57(2), 229-247, doi:10.1080/02626667.2011.637497, 2012.

Tucker, C. J.: Red and photographic infrared linear combinations for monitoring vegetation, Remote Sensing of Environment, 8(2), 127-150, doi:10.1016/0034-4257(79)90013-0, 1979.

Wang-Erlandsson, L., van der Ent, R. J., Gordon, L. J. and Savenije, H. H. G.: Contrasting roles of interception and transpiration in the hydrological cycle - Part 1: Temporal characteristics over land, Earth Syst. Dynam., 5(2), 441-469, doi:10.5194/esd-5-441-2014, 2014.

Woods, S. W. and Balfour, V. N.: The effect of ash on runoff and erosion after a severe forest wildfire, Montana, 25 USA, Int. J. Wildland Fire, 17(5), 535-548, doi:10.1071/WF07040, 2008. 
Hydrol. Earth Syst. Sci. Discuss., https://doi.org/10.5194/hess-2018-387

Manuscript under review for journal Hydrol. Earth Syst. Sci.

Discussion started: 20 August 2018

(c) Author(s) 2018. CC BY 4.0 License.

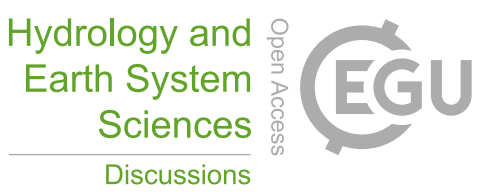

(c) (1)

\section{Appendix}

Table A1. Statistical significance of the Mann-Whitney $U$ test for the changes between model and observation for all flow signature descriptors defined in each catchment (A to D, Figure 1) at annual scales: 1) High significance (99\%) increase ( $\$)$ and decrease (=); 2) Normal significance $(95 \%)$ increase $(+)$ and decrease $(-)$; 3) No significance, $(\cdot)$

\begin{tabular}{lcc} 
& YEAR \\
& ABCD \\
\hline Skew & $\cdot$ & $\cdots$ \\
Qsp & $\cdot$ & $\cdots$ \\
CVQ & $\cdot$ & $\ldots$ \\
BFI & $\cdot$ & $\ldots$ \\
Q5 & $\cdot$ & $\ldots$ \\
HFD & $\cdot$ & $\ldots$ \\
Q95 & - & $\ldots$ \\
LowFr & $\cdot$ & $\ldots$ \\
HighFr & $\cdot$ & $\ldots$ \\
LowDurVar & $\cdot$ & $\ldots$ \\
Mean30dMax & $\cdot$ & $\ldots$ \\
Const & $\cdot$ & $\ldots$ \\
Rev & $\ddagger$ & $\ddagger \ddagger$ \\
RBFlash & $\cdot$ & $\ldots$ \\
RunoffCo & $\cdot$ & $\ldots$ \\
ActET & $\cdot$ & $\ldots$ \\
\hline
\end{tabular}


Hydrol. Earth Syst. Sci. Discuss., https://doi.org/10.5194/hess-2018-387

Manuscript under review for journal Hydrol. Earth Syst. Sci.

Discussion started: 20 August 2018

(c) Author(s) 2018. CC BY 4.0 License.
Hydrology and

Earth System

Sciences

Discussions

(c) (i)

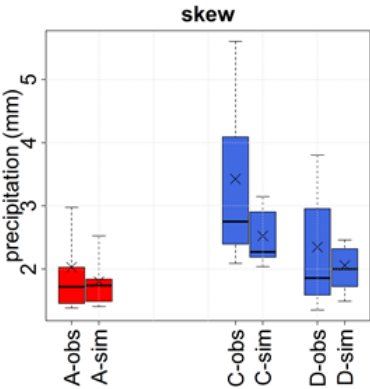

Q5
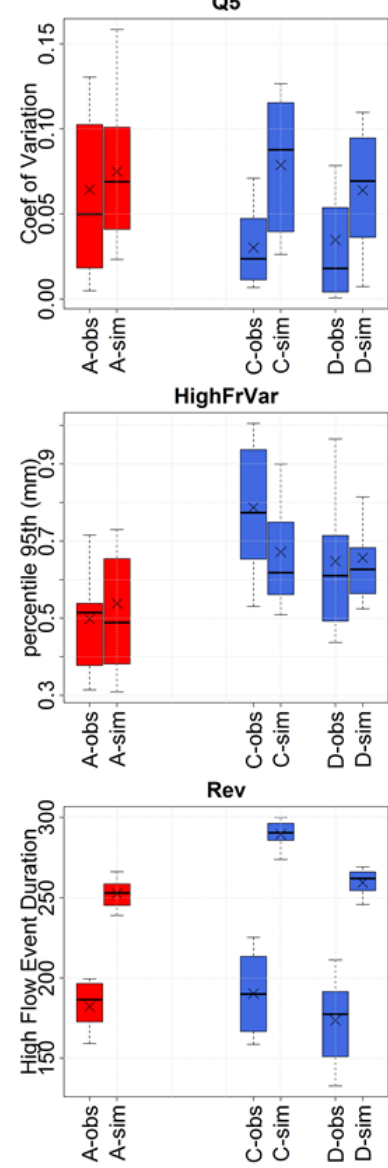
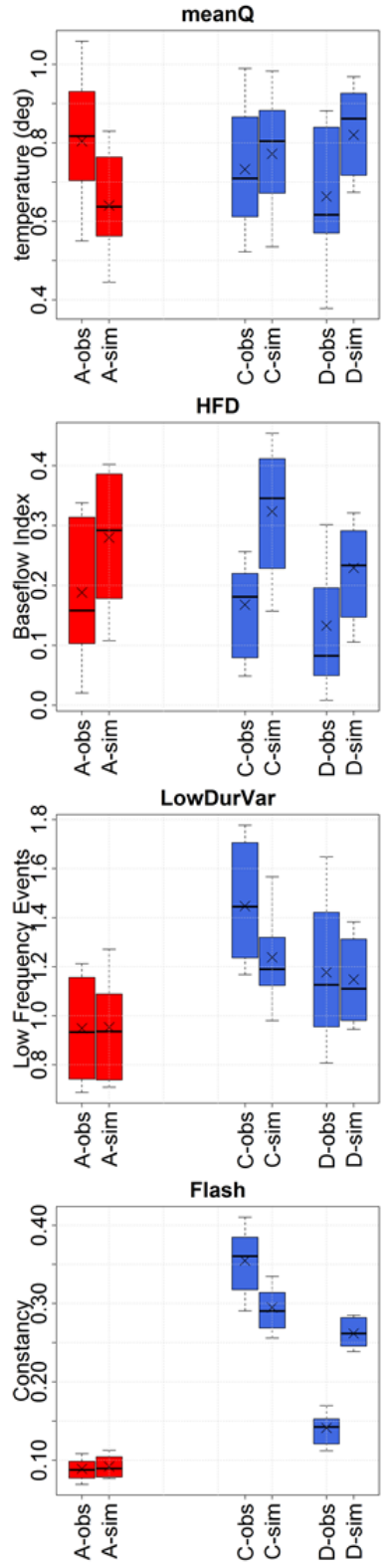
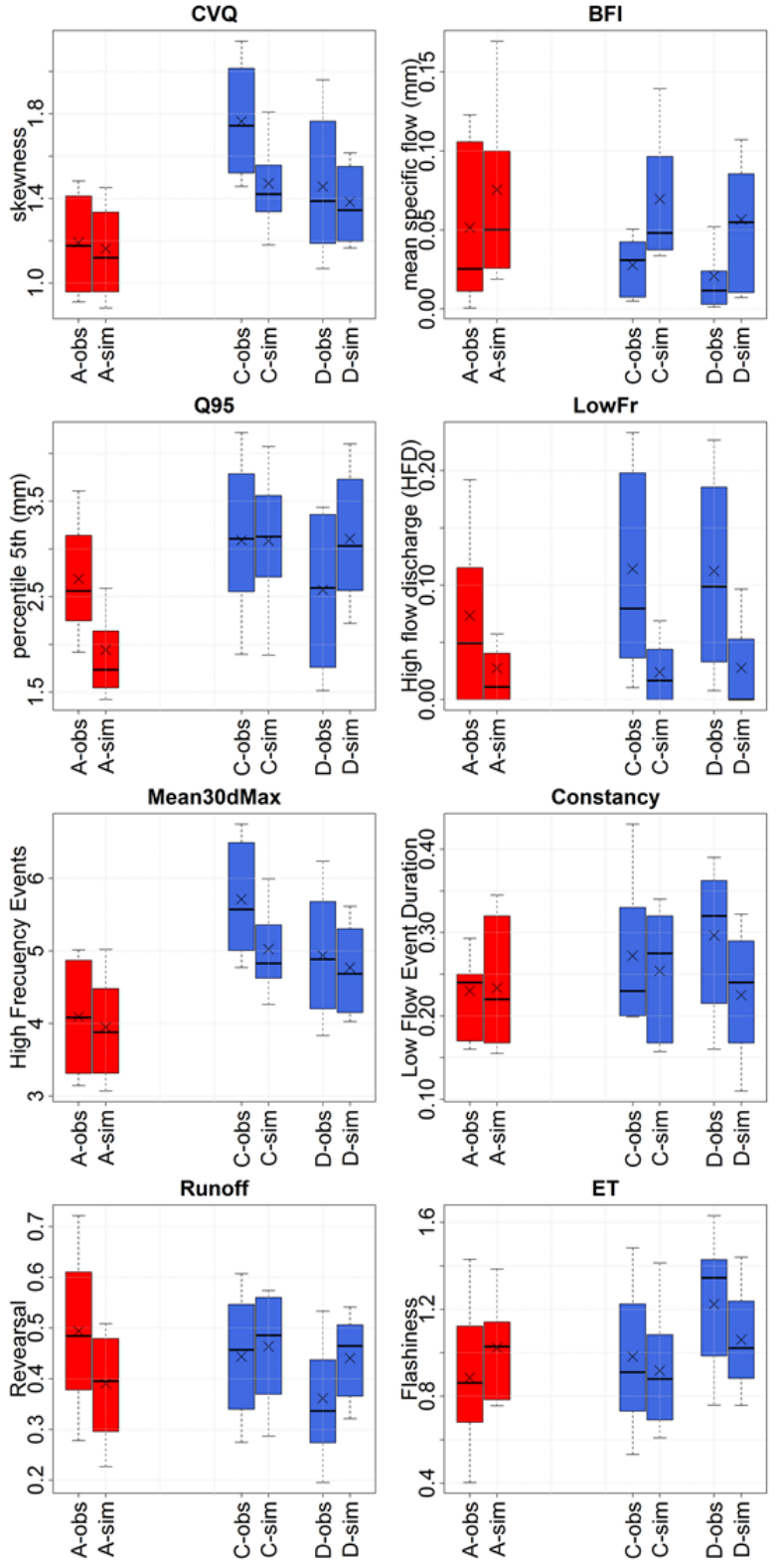

Figure A1 Annual distribution of the 16 flow signatures for observation (Table 1) and simulated (S-HYPE) values in each of the four selected sites. Red box high affected site; orange box mid affected site and blue boxes, non-affected areas. 
Hydrol. Earth Syst. Sci. Discuss., https://doi.org/10.5194/hess-2018-387 Manuscript under review for journal Hydrol. Earth Syst. Sci.

Discussion started: 20 August 2018

(c) Author(s) 2018. CC BY 4.0 License.
Hydrology and Earth System Sciences

Discussions (c) (1)
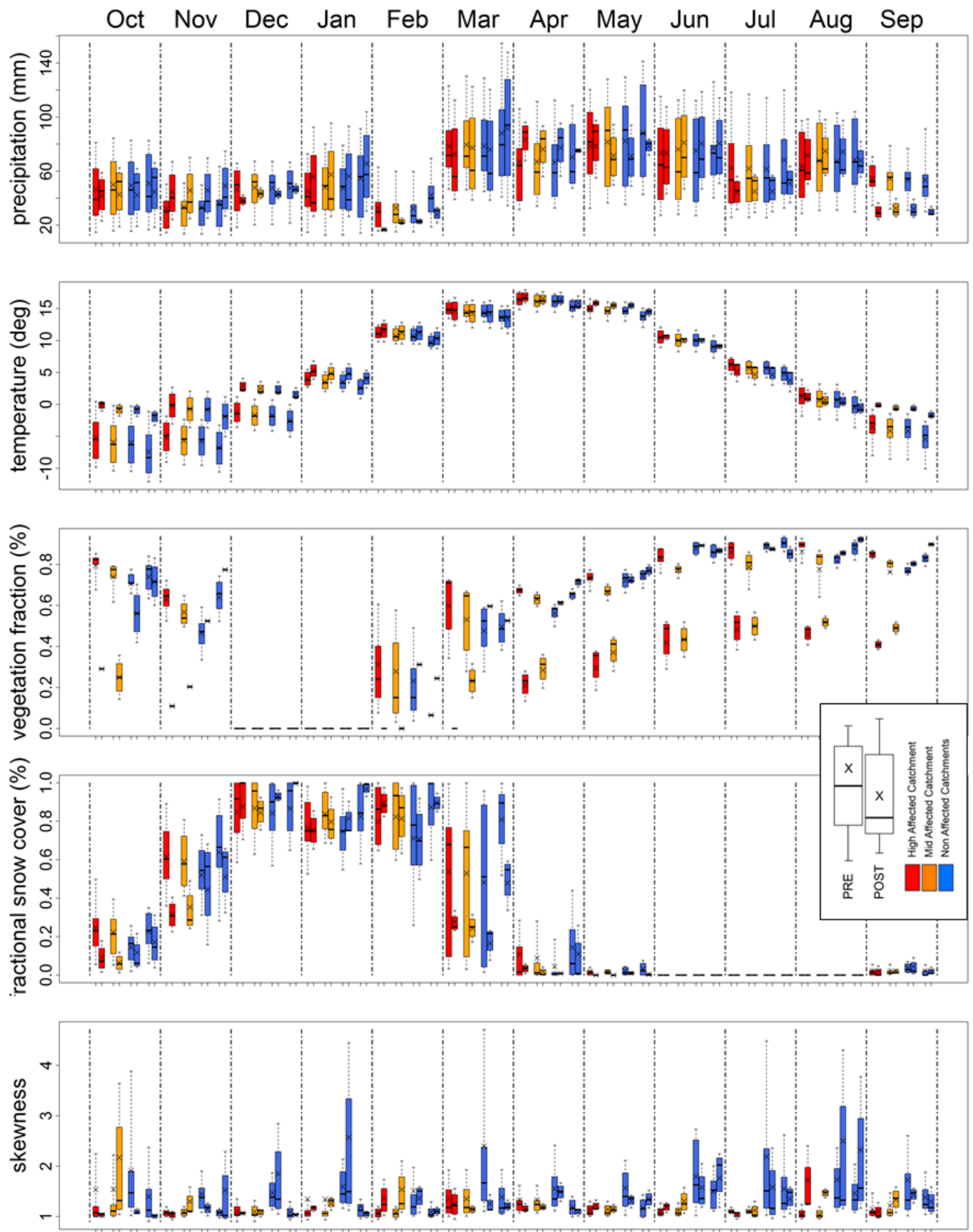

Figure A2 Seasonal distribution of the 13 descriptor defined at monthly scale for the pre- and post-wildfire period in each of the four selected sites. Red box high affected site; orange box mid affected site and blue boxes, non-affected areas. 
Hydrol. Earth Syst. Sci. Discuss., https://doi.org/10.5194/hess-2018-387

Manuscript under review for journal Hydrol. Earth Syst. Sci.

Discussion started: 20 August 2018

(c) Author(s) 2018. CC BY 4.0 License.
Hydrology and

Earth System

Sciences

Discussions

(a) (1)
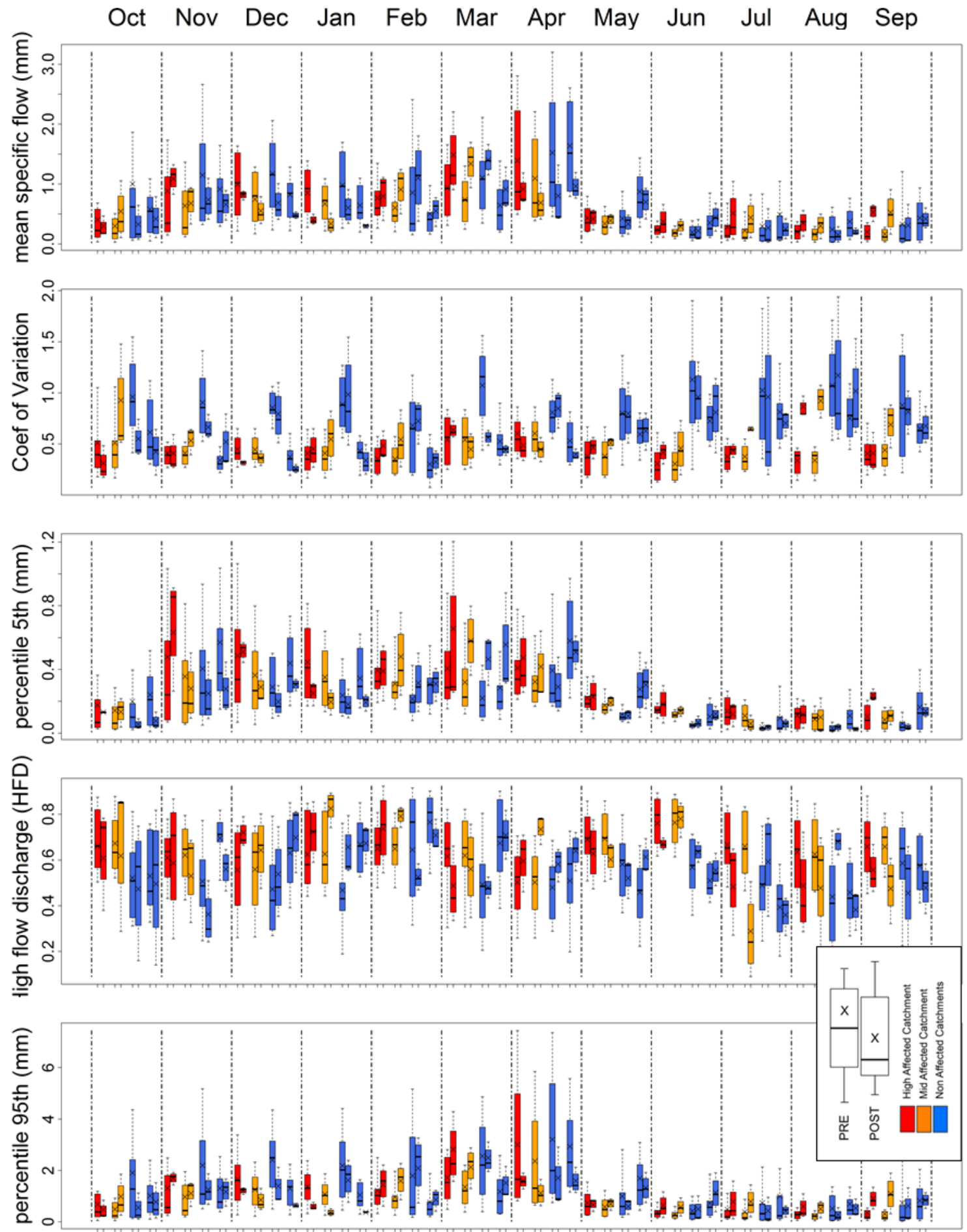

Figure A2 Seasonal distribution of the 13 descriptor defined at monthly scale for the pre- and post- wildfire period in each of the four selected sites. Red box high affected site; orange box mid affected site and blue boxes, non-affected areas (cont) 
Hydrol. Earth Syst. Sci. Discuss., https://doi.org/10.5194/hess-2018-387 Manuscript under review for journal Hydrol. Earth Syst. Sci.

Discussion started: 20 August 2018

(c) Author(s) 2018. CC BY 4.0 License.
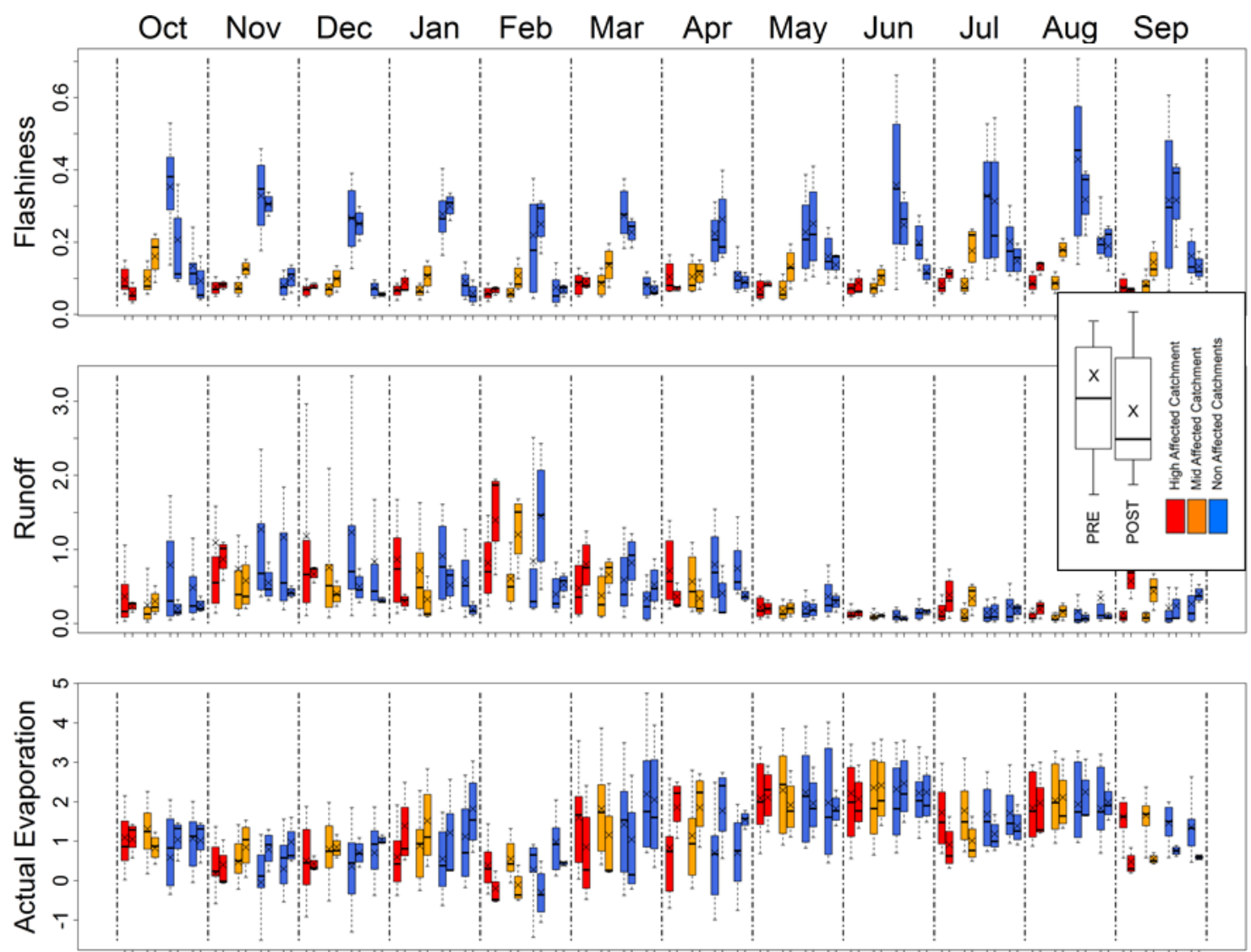

Figure A2 Seasonal distribution of the 13 descriptor defined at monthly scale for the pre- and post-wildfire period in each of the four selected sites. Red box high affected site; orange box mid affected site and blue boxes, non-affected areas (cont) 
Hydrol. Earth Syst. Sci. Discuss., https://doi.org/10.5194/hess-2018-387

Manuscript under review for journal Hydrol. Earth Syst. Sci.

Discussion started: 20 August 2018

(c) Author(s) 2018. CC BY 4.0 License.

(c) (1)

\section{Hydrology and Earth System Sciences Discussions}
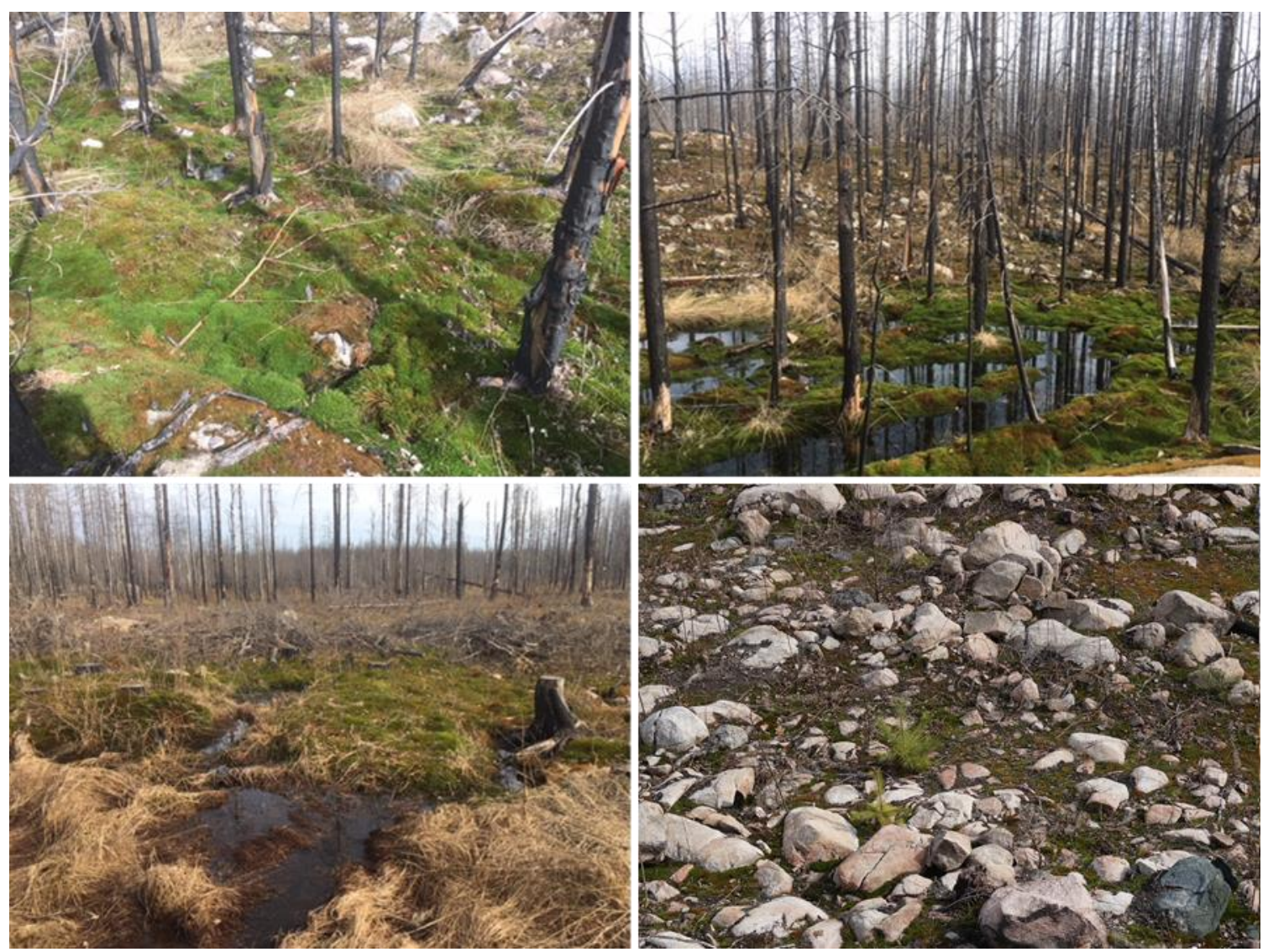

Figure A3. Example of the new vegetation appearing after the wildfire 